\title{
Pesticide Compounds in Streamwater in the Delaware River Basin, December 1998-August 2001
}

Scientific Investigations Report 2004-5105

U.S. Department of the Interior

U.S. Geological Survey 


\section{Pesticide Compounds in Streamwater in the Delaware River Basin, December 1998-August 2001}

Scientific Investigations Report 2004-5105

U.S. Department of the Interior

U.S. Geological Survey 


\section{Pesticide Compounds in Streamwater in the Delaware River Basin, December 1998-August 2001}

By R. Edward Hickman

Prepared as part of the

NATIONAL WATER-QUALITY ASSESSMENT PROGRAM

Scientific Investigations Report 2004-5105 


\title{
U.S. Department of the Interior Gale A. Norton, Secretary
}

\author{
U.S. Geological Survey \\ Charles G. Groat, Director
}

\section{U.S. Geological Survey, Reston, Virginia: 2004}

\author{
For sale by U.S. Geological Survey, Information Services \\ Box 25286, Denver Federal Center \\ Denver, C0 80225 \\ For additional information write to: \\ District Chief \\ U.S. Geological Survey \\ Mountain View Office Park \\ 810 Bear Tavern Road \\ West Trenton, NJ 08628 \\ For more information about the USGS and its products: \\ Telephone: 1-888-ASK-USGS \\ World Wide Web: http://www.usgs.gov/
}

Any use of trade, product, or firm names in this publication is for descriptive purposes only and does not imply endorsement by the U.S. Government.

Although this report is in the public domain, permission must be secured from the individual copyright owners to reproduce any copyrighted materials contained within this report. 


\section{Foreword}

The U.S. Geological Survey (USGS) is committed to serve the Nation with accurate and timely scientific information that helps enhance and protect the overall quality of life, and facilitates effective management of water, biological, energy, and mineral resources. (http://www.usgs.gov/). Information on the quality of the Nation's water resources is of critical interest to the USGS because it is so integrally linked to the long-term availability of water that is clean and safe for drinking and recreation and that is suitable for industry, irrigation, and habitat for fish and wildlife. Escalating population growth and increasing demands for the multiple water uses make water availability, now measured in terms of quantity and quality, even more critical to the long-term sustainability of our communities and ecosystems.

The USGS implemented the National Water-Quality Assessment (NAWQA) Program to support national, regional, and local information needs and decisions related to water-quality management and policy. (http://water.usgs.gov/nawqa/). Shaped by and coordinated with ongoing efforts of other Federal, State, and local agencies, the NAWQA Program is designed to answer: What is the condition of our Nation's streams and ground water? How are the conditions changing over time? How do natural features and human activities affect the quality of streams and ground water, and where are those effects most pronounced? By combining information on water chemistry, physical characteristics, stream habitat, and aquatic life, the NAWQA Program aims to provide science-based insights for current and emerging water issues and priorities. NAWQA results can contribute to informed decisions that result in practical and effective water-resource management and strategies that protect and restore water quality.

Since 1991, the NAWQA Program has implemented interdisciplinary assessments in more than 50 of the Nation's most important river basins and aquifers, referred to as Study Units.

(http://water.usgs.gov/nawqa/nawqamap.html). Collectively, these Study Units account for more than 60 percent of the overall water use and population served by public water supply, and are representative of the Nation's major hydrologic landscapes, priority ecological resources, and agricultural, urban, and natural sources of contamination.

Each assessment is guided by a nationally consistent study design and methods of sampling and analysis. The assessments thereby build local knowledge about water-quality issues and trends in a particular stream or aquifer while providing an understanding of how and why water quality varies regionally and nationally. The consistent, multi-scale approach helps to determine if certain types of water-quality issues are isolated or pervasive, and allows direct comparisons of how human activities and natural processes affect water quality and ecological health in the Nation's diverse geographic and environmental settings. Comprehensive assessments on pesticides, nutrients, volatile organic compounds, trace metals, and aquatic ecology are developed at the national scale through comparative analysis of the Study-Unit findings.

(http://water.usgs.gov/nawqa/natsyn.html).

The USGS places high value on the communication and dissemination of credible, timely, and relevant science so that the most recent and available knowledge about water resources can be applied in management and policy decisions. We hope this NAWQA publication will provide you the needed insights and information to meet your needs, and thereby foster increased awareness and involvement in the protection and restoration of our Nation's waters. 
The NAWQA Program recognizes that a national assessment by a single program cannot address all water-resource issues of interest. External coordination at all levels is critical for a fully integrated understanding of watersheds and for cost-effective management, regulation, and conservation of our Nation's water resources. The Program, therefore, depends extensively on the advice, cooperation, and information from other Federal, State, interstate, Tribal, and local agencies, non-government organizations, industry, academia, and other stakeholder groups. The assistance and suggestions of all are greatly appreciated.

\section{Robert M. Hirsch}

\section{Associate Director for Water}




\section{Contents}

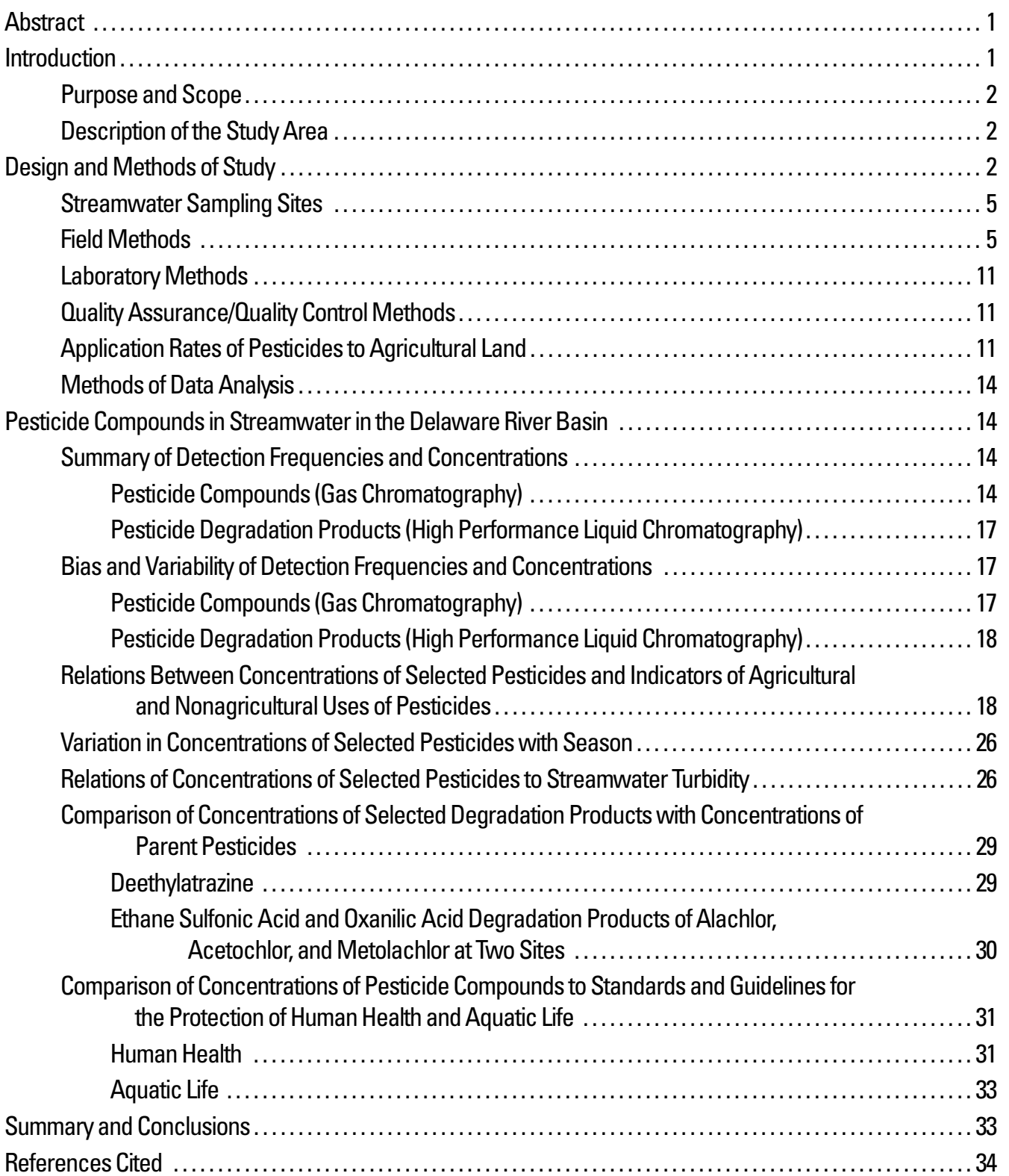




\section{Figures}

1-2. Maps showing-

1. Location of the Delaware River Basin, New York, Pennsylvania, New Jersey,

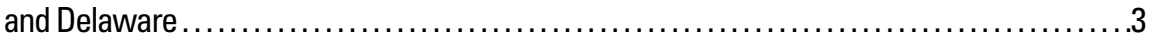

2. Physiographic provinces and land use in the Delaware River Basin, $1992 \ldots \ldots \ldots \ldots \ldots \ldots$

3. Graph showing crops with the largest areas of cultivation in the Delaware River Basin ...........5

4-5. Maps showing-

4. Location of fixed streamwater sampling sites with drainage areas in the Delaware River Basin. 6

5. Location of synoptic and fixed streamwater sampling sites in the Delaware River Basin, 1998-2001. 10

6-8. Graphs showing-

6. Frequences of detection of the pesticide compounds most often detected in 531 samples of streamwater by use of gas chromatography, Delaware River Basin, December 1998-August 2001.

7. Relation of frequency of detection to estimated annual application to agricultural land within the Delaware River Basin. ...

8. Relation of concentration of atrazine in streamwater to percentage of agricultural land in subbasins of the Delaware River Basin, May and June 2000.

9. Map showing streamwater sampling sites and association of atrazine under base-flow conditions, and application rates, Delaware River Basin, May and June 1999-2001 ....

10. Graph showing relation of concentrations of prometon in streamwater to the percentage of urban land in subbasins of the Delaware River Basin, May and June 2000.

11. Map showing streamwater sampling sites and associated concentrations of prometon under base-flow conditions, and population density, Delaware River Basin, May and June 1999-2001. 25

12-17. Graphs showing-

12. Concentrations of $(A)$ atrazine, and $(B)$ acetochlor in streamwater samples from fixed sites in the Delaware River Basin, December 1998-August 2001.

13. Concentrations of $(A)$ prometon, and $(B)$ diazinon in streamwater samples from fixed sites in the Delaware River Basin, December 1998-August 2001.

14. Relation of diazinon concentration to streamwater turbidity at streamwater sampling site 01464907, Little Neshaminy Creek near Neshaminy, Pa., April-October, 1999-2001 . . . . . 29

15. Relation of concentrations of deethylatrazine to concentrations of atrazine in streamwater samples from the Delaware River Basin, 1998-2001

16. Relation of frequency of detection of ethane sulfonic acid and oxanilic acid degradation products to the frequency of detection of metolachlor, alachlor, and acetochlor in 68 streamwater samples from two sites in the Delaware River Basin, 1999-2000...

17. Concentrations of metolachlor and its degradation products at fixed site 01474500 , Schuylkill River at Philadelphia, Pa., March 1999-August 2000. 


\section{Tables}

1. Description of fixed and synoptic streamwater sampling sites in the Delaware River Basin,

December 1998-August 2001. . . . .

2. Pesticides and degradation products analyzed for in streamwater in the Delaware River Basin,

December 1998-August 2001. . ...

3. Summary of the frequencies of detection and the concentrations of pesticide compounds detected in streamwater in the Delaware River Basin, December 1998-August 2001. ...

4. Selected nationwide uses of pesticides detected most often in streamwater in the Delaware River Basin, December 1998-August 2001.

5. Relations of concentrations of selected pesticides in streamwater to rate of application to agricultural land, and relations of concentrations of selected pesticides to percentage of agricultural land in subbasins of the Delaware River Basin, 2000

6. Relations of concentrations of selected pesticides in streamwater to population density, and relations of concentrations of selected pesticides to percentage of urban land in subbasins of the Delaware River Basin, 2000 .

7. Summary of relations of concentrations of selected pesticides to streamwater turbidity at fixed streamwater sampling sites in the Delaware River Basin, April-0ctober, 1999-2001. ...

8. Selected standards and guidelines for the protection of the health of humans and aquatic life from pesticide compounds in streamwater. 


\section{Conversion Factors}

\begin{tabular}{lcl}
\hline Multiply & By & To obtain \\
\hline \multicolumn{1}{l}{ Length } & \\
\hline foot (ft) & 0.3048 & meter $(\mathrm{m})$ \\
\hline square mile $\left(\mathrm{mi}^{2}\right)$ & Area & \\
\hline & 2.590 & square kilometer $\left(\mathrm{km}^{2}\right)$ \\
\hline
\end{tabular}

Concentrations of chemical constituents in water are given either in milligrams per liter $(\mathrm{mg} / \mathrm{L})$ or micrograms per liter $(\mu \mathrm{g} / \mathrm{L})$. 


\title{
Pesticide Compounds in Streamwater in the Delaware River Basin, December 1998-August 2001
}

\author{
By R. Edward Hickman
}

Abstract

During 1998-2001, 533 samples of streamwater at 94 sites were collected in the Delaware River Basin in Pennsylvania, New Jersey, New York, and Delaware as part of the U.S. Geological Survey National Water-Quality Assessment Program. Of these samples, 531 samples were analyzed for dissolved concentrations of 47 pesticide compounds (43 pesticides and 4 pesticide degradation products); 70 samples were analyzed for an additional 6 pesticide degradation products.

Of the 47 pesticide compounds analyzed for in 531 samples, 30 were detected. The most often detected compounds were atrazine ( 90.2 percent of samples), metolachlor (86.1 percent), deethylatrazine ( 82.5 percent), and simazine (78.9 percent). Atrazine, metolachlor, and simazine are pesticides; deethylatrazine is a degradation product of atrazine.

Relations between concentrations of pesticides in samples from selected streamwater sites and characteristics of the subbasins draining to these sites were evaluated to determine whether agricultural uses or nonagricultural uses appeared to be the more important sources. Concentrations of atrazine, metolachlor, and pendimethalin appear to be attributable more to agricultural uses than to nonagricultural uses; concentrations of prometon, diazinon, chlorpyrifos, tebuthiuron, trifluralin, and carbaryl appear to be attributable more to nonagricultural uses.

In general, pesticide concentrations during the growing season (April-October) were greater than those during the nongrowing season (November-March). For atrazine, metolachlor, and acetochlor, the greatest concentrations generally occurred during May, June, and July.

Concentrations of pesticide compounds rarely (in only 7 out of 531 samples) exceeded drinking-water standards or guidelines, indicating that, when considered individually, these compounds present little hazard to the health of the public through consumption of the streamwater. The combined effects of more than one pesticide compound in streamwater were not considered.

Diazinon appeared to be the pesticide compound most likely to adversely affect aquatic life in the streams of the Delaware River Basin; concentrations of diazinon exceeded guidelines (designed to protect aquatic life) in 19 samples, the most of any pesticide compound. Concentrations of as many as 5 compounds exceeded guidelines in 29 of 531 samples.

\section{Introduction}

Pesticides have been detected in streams draining urban and agricultural areas throughout the Nation (Fuhrer and others, 1999). Most pesticides are synthetic organic compounds designed to kill specific plants or insects on selected sites, such as agricultural land, lawns, golf courses, roadsides, or in or around buildings. Their presence in streamwater is the result of transport by ground-water discharge, surface runoff, or other processes from sites of application to streams.

Pesticides in streams are of concern to water-resource managers and drinking-water suppliers because pesticides can adversely affect the health of the aquatic biota in the streams and(or) the health of humans who drink the streamwater. Fuhrer and others (1999) consider the presence of pesticides in streamwater to be a potential concern because of uncertainties in the methods used to assess the effects of pesticide concentrations on the health of aquatic biota and the health of humans and because these methods do not address all effects. For example, an assessment of the health effects of a pesticide does not usually include the health effects of its degradation products (compounds created from the breakdown of the pesticide).

Pesticide concentrations in streamwater of the Delaware River Basin in Pennsylvania, New Jersey, New York, and Delaware were measured by the U.S. Geological Survey (USGS) at sites throughout the basin from December 1998 through August 2001. These concentrations, as well as other measurements of water quality, have been published in DeLuca and others (2000, 2001, and 2002).

Samples of streamwater in the Delaware River Basin were collected as part of the USGS National Water-Quality Assessment (NAWQA) Program, a study of the quality of the Nation's surface and ground water. The national goals of this program are to (1) describe current water-quality conditions of much of the Nation's freshwater streams and aquifers (water-bearing sediments and rocks), (2) describe how water quality is changing over time, and (3) increase our understanding of the natural and human factors that affect water quality (Leahy and others, 1990; Gilliom and others, 1995). The Delaware River Basin NAWQA Program also provides information to address local concerns, which include (1) the presence of pesticides in drinking-water supplies and recreational waters, and (2) relations between land use and nonpoint sources of contaminants (Fischer, 1999). 


\section{Pesticide Compounds in Streamwater in the Delaware River Basin, December 1998-August 2001}

\section{Purpose and Scope}

This report presents the results of analyses of 533 streamwater samples collected at 94 sites in the Delaware River Basin from December 1998 to August 2001 for selected pesticide compounds (pesticides and pesticide degradation products). Of these samples, 531 samples were analyzed for 43 pesticides and 4 degradation products; these pesticides are those that have been, or are currently (2004), in common use throughout the Nation. In addition, 70 streamwater samples from 2 sites were analyzed for 6 other pesticide degradation products.

Concentrations and frequencies of detection are summarized by pesticide compound. Bias and variability of detections and concentrations as indicated by quality-assurance/qualitycontrol (QA/QC) samples are presented.

Factors that appear to affect the detection and concentration of selected pesticide compounds are discussed. The importance of nonagricultural uses and agricultural uses of pesticides as sources of pesticide compounds to streams was inferred from relations between concentrations and selected subbasin characteristics. Relations between (1) pesticide concentration and season and (2) concentration and streamwater turbidity are presented. Concentrations of selected pesticide degradation products are compared with concentrations of parent pesticides.

A measure of the hazard which pesticide compounds in streamwater appears to represent to human health and aquatic life is assessed. Concentrations of pesticide compounds are compared to standards and guidelines for drinking water and for the protection of aquatic life.

\section{Description of the Study Area}

The study area of the Delaware River Basin NAWQA study unit is the Delaware River Basin other than that part of the basin in the central and southern parts of the State of Delaware (fig. 1). The basin includes $12,100 \mathrm{mi}^{2}$ of the States of New York, Pennsylvania, New Jersey, and Delaware.

Five physiographic provinces are represented in the study area (fig. 2). In the northern part of the basin, the rugged hills and broad ridges of the Appalachian Plateaus rise to an elevation of about 4,000 ft. The Valley and Ridge Province consists of a series of valleys and ridges, and the New England Province is one ridge. The Piedmont Province is characterized by a series of rolling hills and broad uplands. The Coastal Plain, the southernmost province, has the lowest elevation (generally less than $200 \mathrm{ft}$ above sea level) and is relatively flat as compared to the other provinces. Land elevation generally decreases from the Appalachian Plateaus in the north to the Coastal Plain in the south.

Land use in the study area was determined from 1992 satellite imagery. Overall, the study area consists of 60 percent for- ested, 24 percent agricultural, 9 percent urban, and 7 percent other land uses, which includes water, bare rock, mines, orchards, grasslands, and wetlands (Fischer, 1999).

Most of the population and urban land is in the southern part of the study area in the Piedmont and Coastal Plain Provinces (fig. 2). In 2000, about 85 percent of the 7 million inhabitants of the study area lived within these two provinces; most people lived in and around Philadelphia, Pa., the largest city in the study area.

Most of the agricultural land is in the central and southern parts of the study area. About 80 percent of the agricultural land in the study area is within the Valley and Ridge, Piedmont, and Coastal Plain Provinces (fig. 2). Corn and soybeans are the crops with the largest areas of cultivation in the study area (fig. 3).

Most of the forested land is in the central and northern parts of the study area. About 70 percent of the forested land in the study area is in the Appalachian Plateaus and Valley and Ridge Provinces (fig. 2). The Appalachian Plateaus Province is about 80 percent forested.

The major rivers in the study area are the Delaware, Lehigh, and Schuylkill (fig. 1). The head of tide of the Delaware River is at Trenton, N.J.; that of the Schuylkill River is at Philadelphia.

Reservoirs throughout the study area provide storage for water supply, recreation, and flood control. Some of the larger reservoirs are shown in figure 1 . Streamflow in the rivers downstream from the reservoirs is affected by reservoir operation.

Streamwater throughout the Delaware River Basin is used for public supply. Withdrawals for public water supply are made from reservoirs as well as from streams. The City of Philadelphia makes the largest municipal withdrawals for public water supply within the basin; withdrawals are made from the Delaware and Schuylkill Rivers.

Streamwater also is transferred out of the Delaware River Basin for use elsewhere. The City of New York withdraws water from the Neversink, Pepacton, and Cannonsville Reservoirs (fig. 1). The New Jersey State Water Supply Authority withdraws water from the Delaware River near Trenton for use in eastern New Jersey.

\section{Design and Methods of Study}

The design and methods of this study are common to all USGS NAWQA studies in order that results from one NAWQA study can be compared directly with results from another NAWQA study. A general discussion of the design of NAWQA studies can be found in Gilliom and others (1995). 


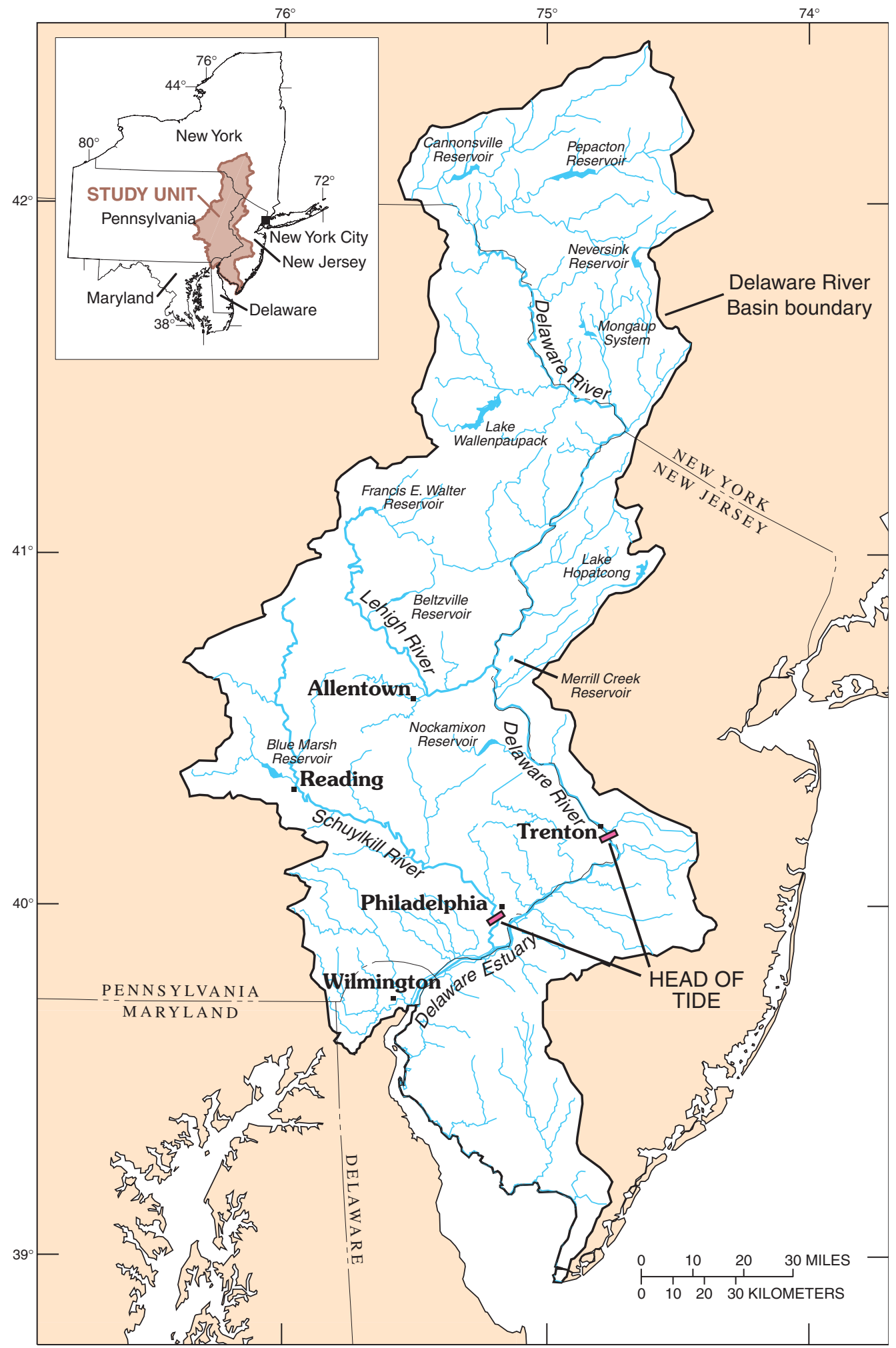

Figure 1. Location of the Delaware River Basin, New York, Pennsylvania, New Jersey, and Delaware. 


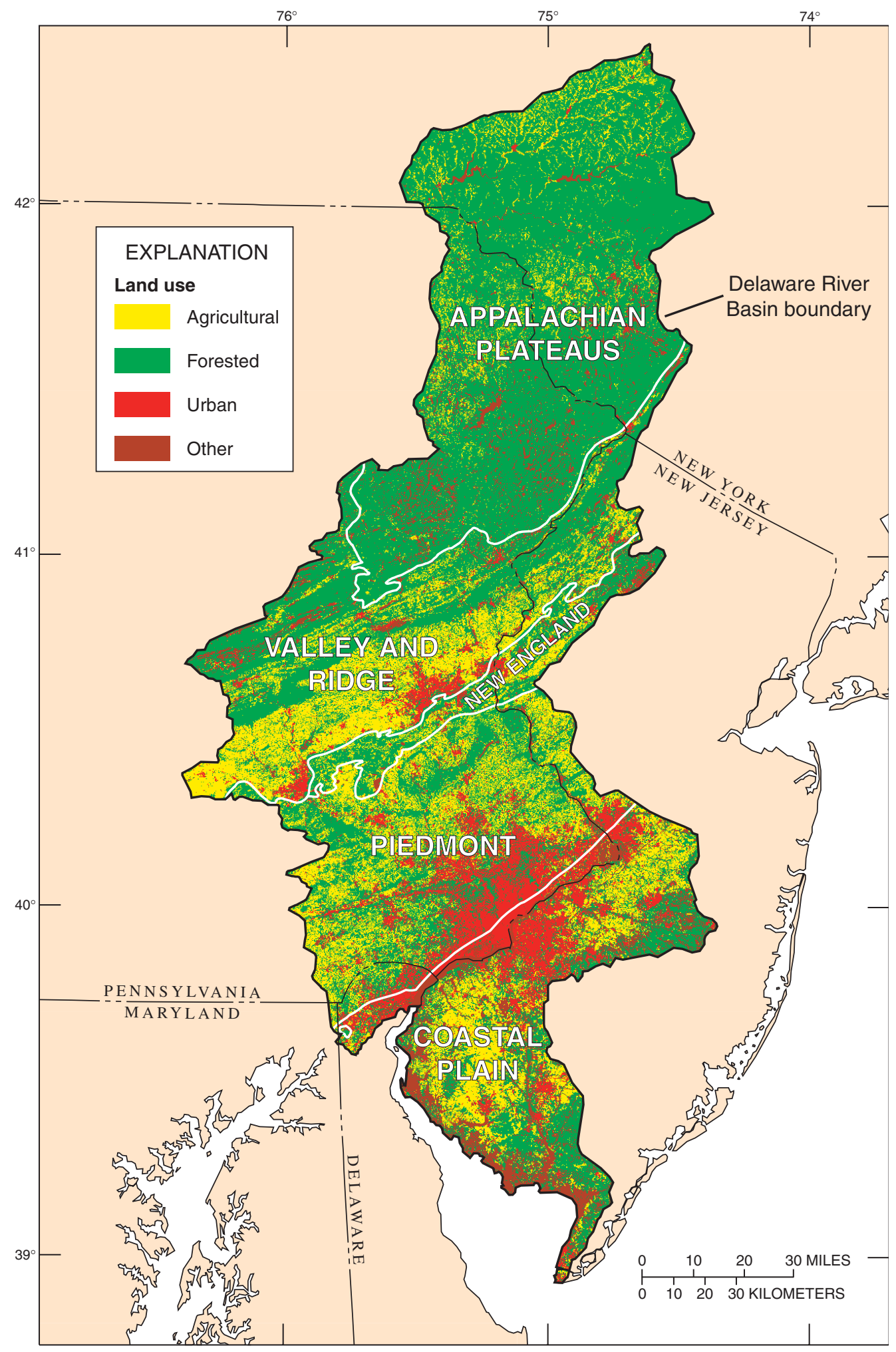

Figure 2. Physiographic provinces and land use in the Delaware River Basin, 1992. 


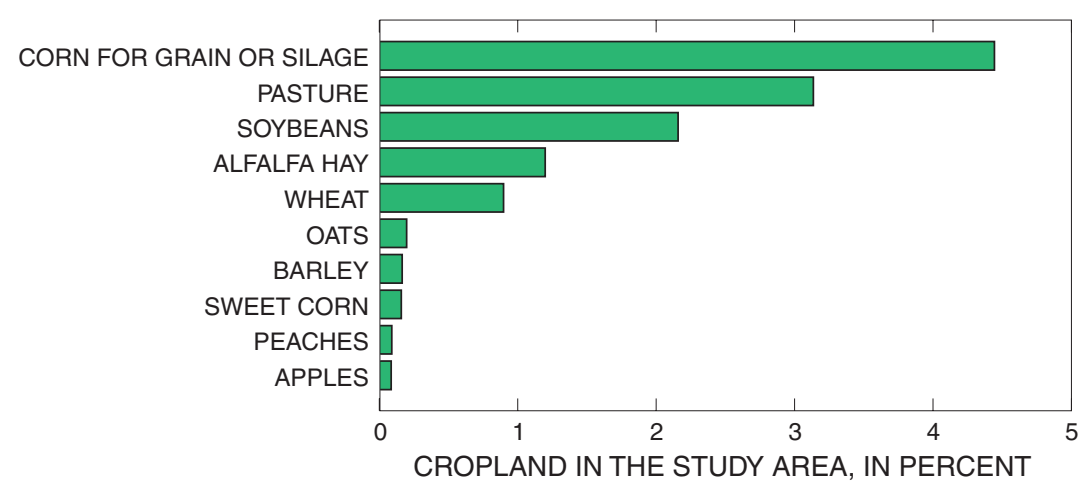

Figure 3. Crops with the largest areas of cultivation in the Delaware River Basin. (Data are from Gianessi and Marcelli, 2000.)

\section{Streamwater Sampling Sites}

Two types of streamwater sites were sampled, "fixed" and "synoptic". Ten fixed sites were sampled throughout the year to provide detailed information about the variation of pesticide concentrations and loads during storms and base flow (between storms) (fig. 4; table 1). In general, fixed sites were sampled at least monthly and during some storms from December 1998 through August 2001. For this report, base-flow conditions in smaller subbasins (17-66.5 $\mathrm{mi}^{2}$ ) generally were considered to exist after about a week of no precipitation; in the larger subbasins, base-flow conditions sometimes took 2 weeks or longer to develop. In this report, the term, 'subbasin', refers to the area draining to each streamwater sampling site.

The following four fixed sites, known as "integrator" sites, were sampled to determine the water quality of the streams draining large subbasins with different land uses and geology (fig. 4; table 1): 01434000, Delaware River at Port Jervis, N.Y.; 01454700, Lehigh River at Glendon, Pa.; 01463500 Delaware River at Trenton, N.J.; and 01474500, Schuylkill River at Philadelphia, $\mathrm{Pa}$. The sizes of the subbasins range from 1,359 to $6,780 \mathrm{mi}^{2}$.

The other six fixed sites, known as "indicator" sites, are on streams with small subbasins (17-66.5 $\mathrm{mi}^{2}$ ) (fig. 4; table 1). These sites were sampled to relate streamwater quality to subbasin geology and land use. Of these, the following two are in subbasins considered to be predominantly urban: 01464907 , Little Neshaminy Creek near Neshaminy, Pa.; and 01467150, Cooper River at Haddonfield, N.J. Land use was determined from satellite images captured during 1992; the subbasin of the site on the Little Neshaminy Creek had more agricultural land (32 percent of the subbasin) than urban land ( 26 percent) in 1992. This subbasin was reclassified as urban after inspection of the subbasin by project personnel who found considerable recent urbanization, however. The following four sites are on subbasins considered to be predominantly agricultural:
01451800, Jordan Creek near Schnecksville, Pa.; 01470779, Tulpehocken Creek near Bernville, Pa.; 01472157, French Creek near Phoenixville, Pa.; and 01477120, Raccoon Creek near Swedesboro, N.J.

Synoptic sites were sampled during base-flow conditions to better understand the areal variation in streamwater quality and relations between water quality and subbasin characteristics, such as land use and geology (fig. 5, table 1). At most of these sites, samples were collected during spring (mostly during May-June) and late summer (mostly during August-September) of 1999, 2000, or 2001. During 1999, 24 sites were sampled to identify the quality of surface water throughout the study area. During 2000, 40 sites were sampled during spring to relate water quality to urban and agricultural land use in the Piedmont and Valley and Ridge Provinces; only 30 sites in the Piedmont Province were sampled during late summer. During 2001, 23 sites were sampled to determine relations between streamwater quality and land use in the Appalachian Plateaus. Three synoptic sites were sampled during spring and late summer of each year.

\section{Field Methods}

Field methods used for streamwater sampling are described in Shelton (1994). A discharge-integrated sample was collected from the stream and split into subsamples, one of which was filtered through a 0.70-micron glass-fiber filter (Sandstrom, 1995). The filtrate was chilled with ice and transported to the laboratory for analysis for pesticide compounds. Sampling and field-processing equipment was cleaned prior to the collection of each sample.

Streamwater turbidity was measured with an YSI 6820 model water-quality meter fitted with a nephelometric turbidimeter. The value of turbidity at the time each sample is collected usually is the median of multiple measurements across the stream width. 


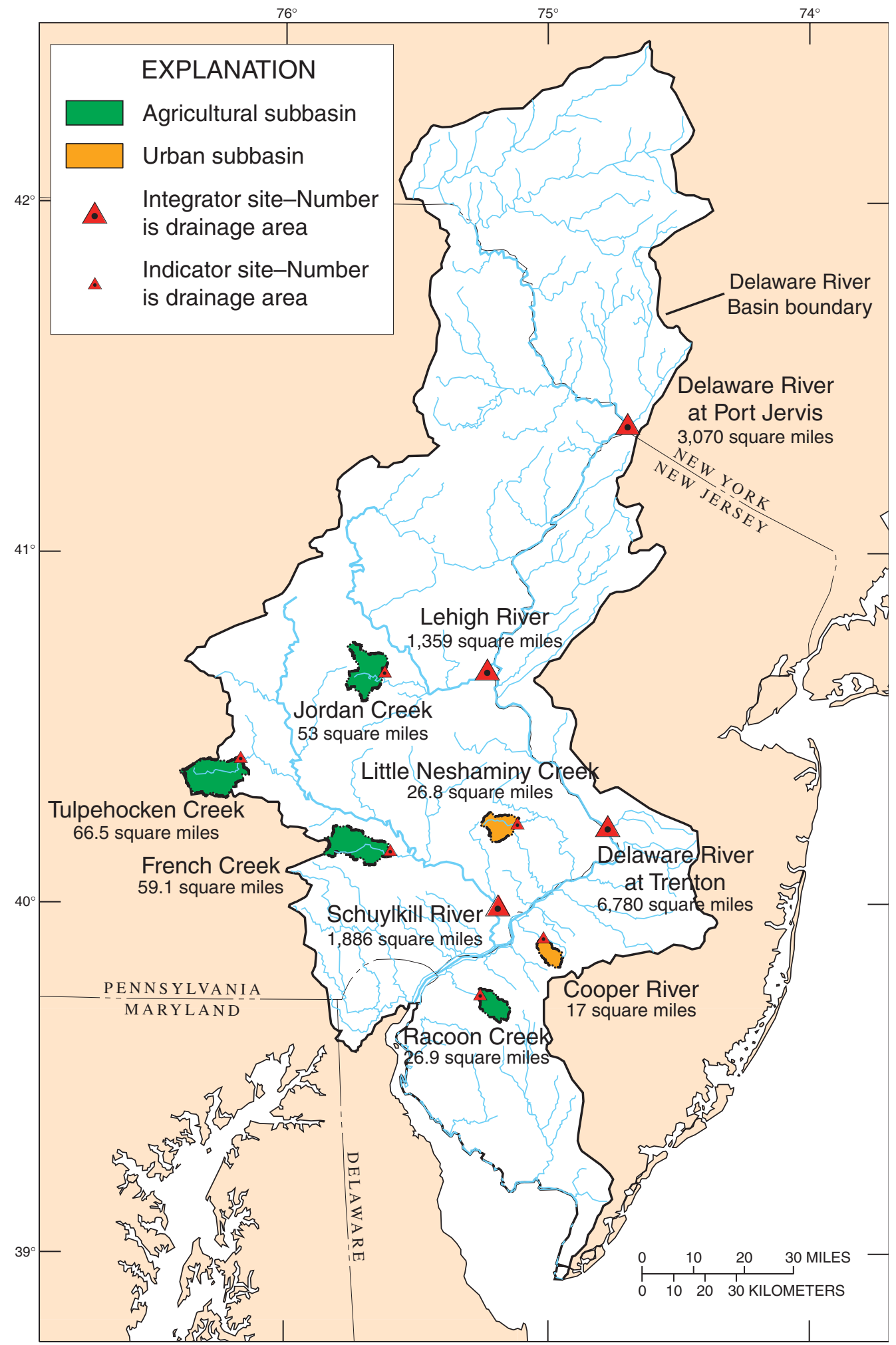

Figure 4. Location of fixed streamwater sampling sites with drainage areas in the Delaware River Basin. 
Table 1. Description of fixed and synoptic streamwater sampling sites in the Delaware River Basin, December 1998-August 2001.

[Locations of fixed sites are shown in figures 4 and 5; locations of synoptic sites are shown in figure 5]

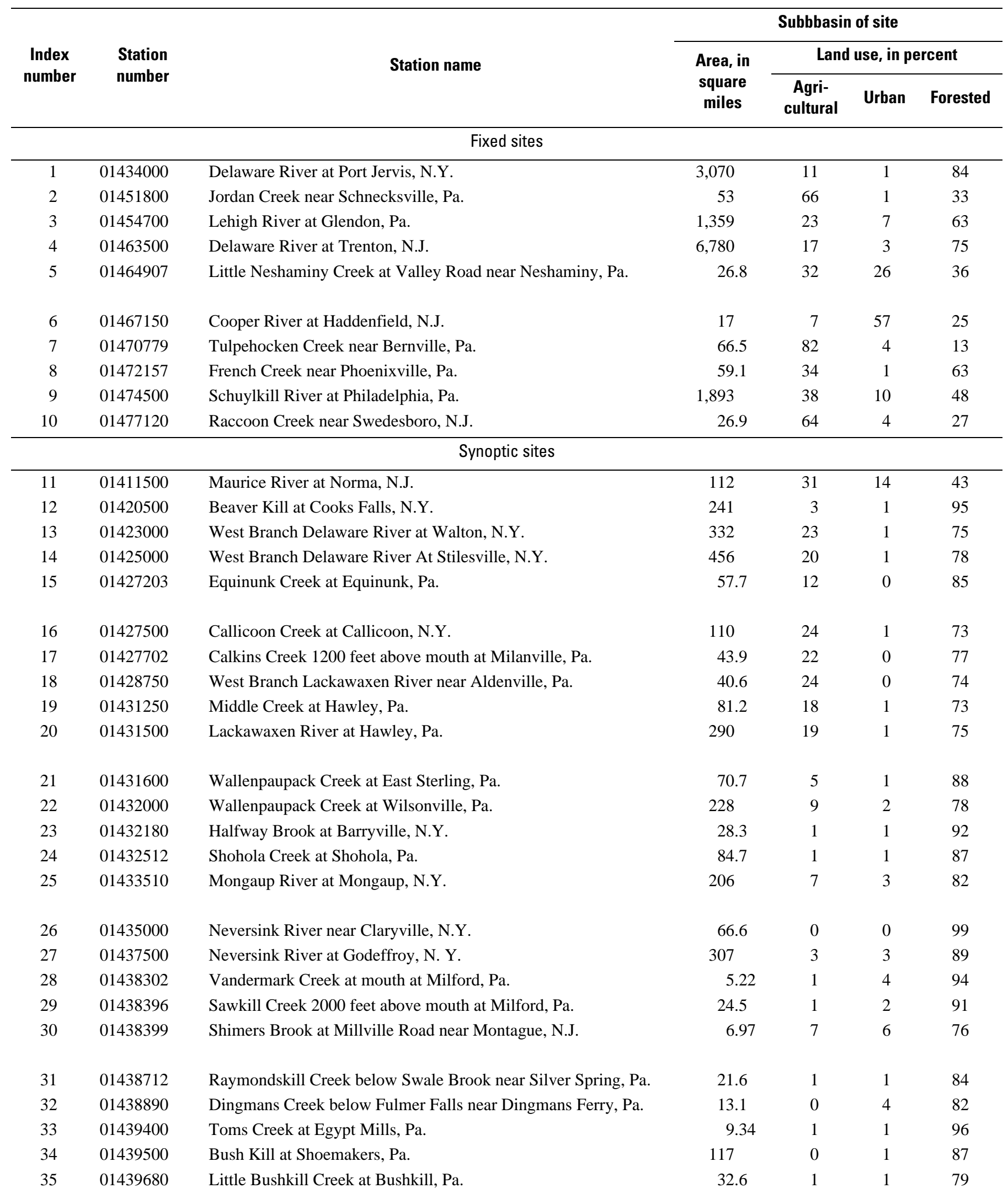




\section{$8 \quad$ Pesticide Compounds in Streamwater in the Delaware River Basin, December 1998-August 2001}

Table 1. Description of fixed and synoptic streamwater sampling sites in the Delaware River Basin, December 1998-August 2001. -Continued

[Locations of fixed sites are shown in figures 4 and 5; locations of synoptic sites are shown in figure 5]

\begin{tabular}{|c|c|c|c|c|c|c|}
\hline \multirow{3}{*}{$\begin{array}{l}\text { Index } \\
\text { number }\end{array}$} & \multirow{3}{*}{$\begin{array}{l}\text { Station } \\
\text { number }\end{array}$} & \multirow{3}{*}{ Station name } & \multicolumn{4}{|c|}{ Subbbasin of site } \\
\hline & & & \multirow{2}{*}{$\begin{array}{l}\text { Area, in } \\
\text { square } \\
\text { miles }\end{array}$} & \multicolumn{3}{|c|}{ Land use, in percent } \\
\hline & & & & $\begin{array}{c}\text { Agri- } \\
\text { cultural }\end{array}$ & Urban & Forested \\
\hline \multicolumn{7}{|c|}{ Synoptic sites--Continued } \\
\hline 36 & 01440000 & Flat Brook near Flatbrookville, N.J. & 64 & 7 & 1 & 88 \\
\hline 38 & 01442500 & Brodhead Creek at Minisink Hills, Pa. & 259 & 7 & 5 & 83 \\
\hline 39 & 01442550 & Marshalls Creek near Marshalls Creek, Pa. & 10.6 & 1 & 0 & 93 \\
\hline 40 & 01443500 & Paulins Kill at Blairstown, N.J. & 126 & 26 & 5 & 59 \\
\hline 41 & 01447000 & Delaware River at Northampton Street at Easton, Pa. & 4,717 & 12 & 2 & 81 \\
\hline 45 & 01450400 & Lizard Creek at Ashfield, Pa. & 46.5 & 32 & 0 & 67 \\
\hline 46 & 01450455 & Buckwha Creek at Little Gap, Pa. & 42.5 & 32 & 1 & 66 \\
\hline 47 & 01451110 & Hokendauqua Creek near Northampton, Pa. & 38.1 & 52 & 1 & 46 \\
\hline 48 & 01451425 & Little Lehigh Creek near East Texas, Pa. & 51.2 & 68 & 8 & 23 \\
\hline 49 & 01451624 & Cedar Creek above Lake Muhlenberg at Allentown, Pa. & 13.7 & 40 & 41 & 17 \\
\hline 50 & 01452500 & Monocacy Creek at Bethlehem, Pa. & 44.5 & 67 & 10 & 19 \\
\hline 51 & 01457400 & Musconetcong River at Riegelsville, N.J. & 156 & 22 & 9 & 60 \\
\hline 52 & 01458920 & Tinicum Creek near Smithtown, Pa. & 24 & 20 & 1 & 77 \\
\hline 58 & 01462949 & Buck Creek below Brock Creek at Yardley, Pa. & 6.89 & 45 & 23 & 26 \\
\hline 59 & 01463810 & Shabakunk Creek near Lawrenceville, N.J. & 11.7 & 14 & 62 & 16 \\
\hline 60 & 01464500 & Crosswicks Creek at Extonville, N.J. & 81.5 & 36 & 7 & 44 \\
\hline 61 & 01464710 & Pine Run at Chalfont, Pa. & 11.6 & 49 & 12 & 37 \\
\hline 62 & 01465470 & Mill Creek near Langhorne, Pa. & 14.6 & 18 & 43 & 32 \\
\hline 63 & 01465500 & Neshaminy Creek near Langhorne, Pa. & 210 & 39 & 20 & 37 \\
\hline 64 & 01467000 & North Branch Rancocas Creek at Pemberton, N.J. & 118 & 4 & 8 & 63 \\
\hline 65 & 01467040 & Pennypack Creek at Paper Mill, Pa. & 23.74 & 5 & 63 & 23 \\
\hline 66 & 0146708450 & Tacony Creek at Cheltenham, Pa. & 9.45 & 0 & 67 & 26 \\
\hline 67 & 01470500 & Schuylkill River at Berne, $\mathrm{Pa}$. & 355 & 15 & 4 & 72 \\
\hline 68 & 01470640 & Ontelaunee Creek at Wanamakers, Pa. & 26.8 & 54 & 1 & 44 \\
\hline 69 & 01470744 & Mill Creek at Dietricks Mill Bridge near Kutztown, $\mathrm{Pa}$. & 17.60 & 72 & 0 & 27 \\
\hline 70 & 01470818 & Little Northkill Creek near Bernville, Pa. & 21.2 & 68 & 1 & 29 \\
\hline
\end{tabular}


Table 1. Description of fixed and synoptic streamwater sampling sites in the Delaware River Basin, December 1998-August 2001. -Continued

[Locations of fixed sites are shown in figures 4 and 5; locations of synoptic sites are shown in figure 5]

\begin{tabular}{|c|c|c|c|c|c|c|}
\hline \multirow{3}{*}{$\begin{array}{c}\text { Index } \\
\text { number }\end{array}$} & \multirow{3}{*}{$\begin{array}{l}\text { Station } \\
\text { number }\end{array}$} & \multirow{3}{*}{ Station name } & \multicolumn{4}{|c|}{ Subbbasin of site } \\
\hline & & & \multirow{2}{*}{$\begin{array}{c}\text { Area, in } \\
\text { square } \\
\text { miles }\end{array}$} & \multicolumn{3}{|c|}{ Land use, in percent } \\
\hline & & & & $\begin{array}{c}\text { Agri- } \\
\text { cultural }\end{array}$ & Urban & Forested \\
\hline \multicolumn{7}{|c|}{ Synoptic sites--Continued } \\
\hline 71 & 01471520 & Wyomissing Crreek at West Reading, Pa. & 15.6 & 25 & 31 & 43 \\
\hline 73 & 01471980 & Manatawny Creek near Pottstown, Pa. & 85.5 & 41 & 2 & 56 \\
\hline 74 & 01472000 & Schuylkill River at Pottstown, Pa. & 1,147 & 40 & 5 & 50 \\
\hline 75 & 01472100 & Pigeon Creek near Parker Ford, Pa. & 14 & 46 & 3 & 51 \\
\hline 76 & 014721884 & Pickering Creek at Charlestown Road Bridge at Charlestown, Pa. & 27.5 & 48 & 4 & 47 \\
\hline 80 & 01474000 & Wissahickon Creek at mouth, Philadelphia, Pa. & 64 & 11 & 43 & 40 \\
\hline 81 & 01475430 & Darby Creek at Foxcroft, Pa. & 15.7 & 13 & 35 & 50 \\
\hline 82 & 01475510 & Darby Creek near Darby, Pa. & 37.4 & 7 & 51 & 38 \\
\hline 83 & 01475543 & Cobbs Creek at East Lansdowne, $\mathrm{Pa}$ & 12.5 & 0 & 71 & 21 \\
\hline 84 & 01475845 & Crum Creek at Goshen Road near Whitehorse, Pa. & 12.5 & 20 & 17 & 60 \\
\hline 85 & 01476470 & Ridley Creek near Media, Pa. & 27.3 & 29 & 11 & 59 \\
\hline 86 & 01476950 & West Branch Chester Creek near Chester Heights, Pa. & 18 & 30 & 16 & 53 \\
\hline 87 & 01478200 & Middle Branch White Clay Creek near Landenberg, Pa. & 12.7 & 68 & 4 & 27 \\
\hline 93 & 01480890 & Valley Creek near Altor, Pa. & 16 & 26 & 23 & 46 \\
\hline 94 & 01481500 & Brandywine Creek at Wilmington, Del. & 314 & 44 & 8 & 45 \\
\hline
\end{tabular}




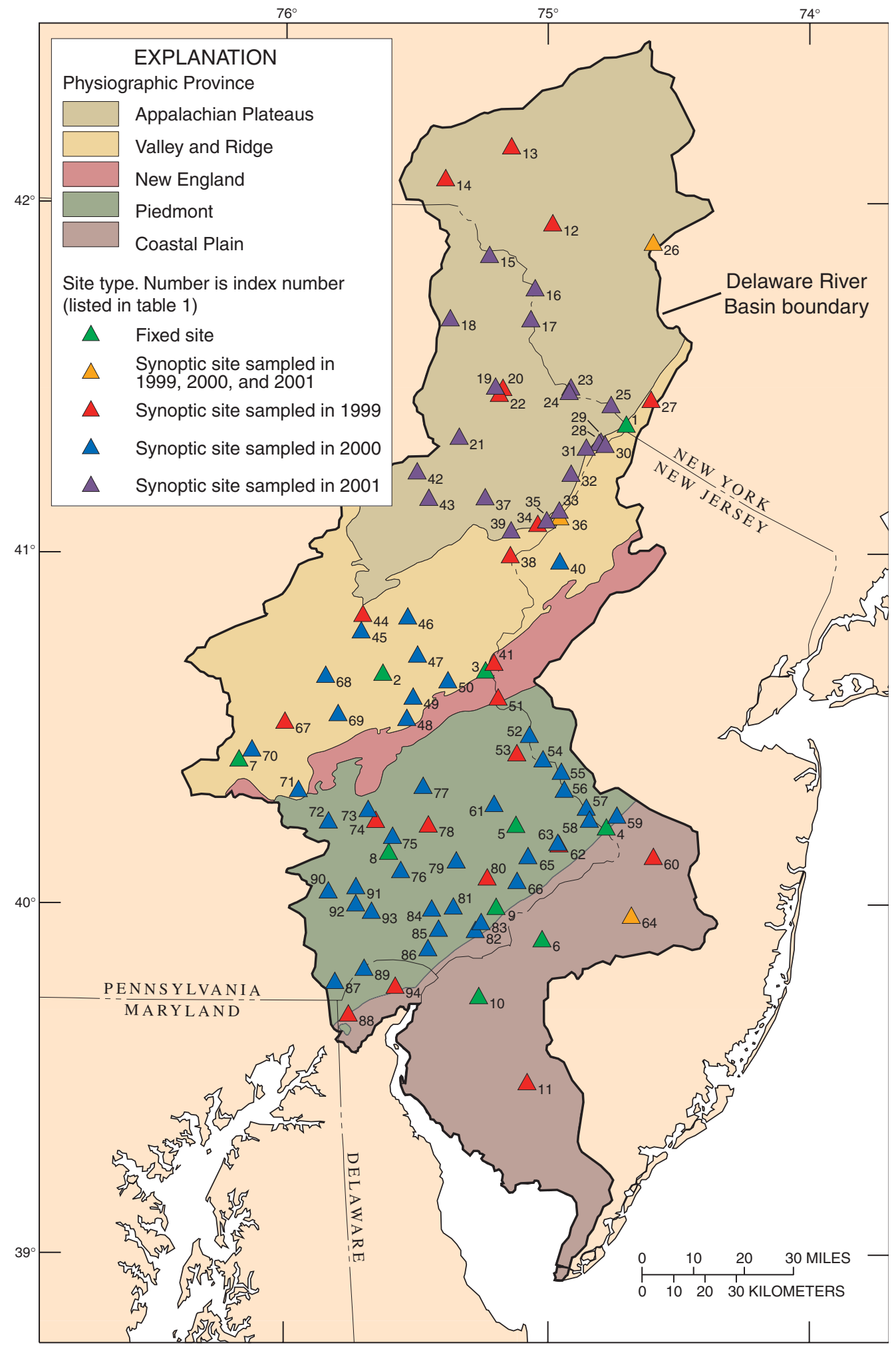

Figure 5. Location of synoptic and fixed streamwater sampling sites in the Delaware River Basin, 1998-2001. 


\section{Laboratory Methods}

Two laboratory methods were used to determine the concentration of pesticide compounds. All concentrations of pesticide compounds are dissolved.

Solid-phase extraction with gas chromatography/mass spectrometry (Zaugg and others, 1995) was used to determine concentrations of 47 pesticide compounds. The 43 pesticides and 4 degradation products (table 2 ) are referred to as "GC pesticide compounds" in this report. For each compound, the laboratory reported one of three types of concentrations: an uncensored value, a nondetected value, or an estimated value. Uncensored values indicate that the concentrations have been determined reliably at values greater than or equal to the laboratory reporting level (some laboratory reporting levels changed during the period of study). Nondetected values indicate that the compound was not detected at concentrations greater than, equal to, or less than the laboratory-reporting level. Estimated values indicate that the laboratory detected but could not reliably quantify the concentration of the compound; estimated values may be greater than, equal to, or less than the laboratory reporting level. All detected concentrations of the following five compounds could not be quantified reliably and were estimated: deethylatrazine, carbofuran, carbaryl, terbacil, and methyl azinphos.

High-performance liquid chromatography/mass spectrometry (Lee and others, 2001) was used to determine the concentrations of six additional pesticide degradation products (table 2). The ethane sulfonic acid (ESA) and oxanilic acid (OA) degradation products of acetochlor, alachlor, and metolachlor are referred to as "HPLC pesticide degradation products" in this report. The laboratory reported either nondetected values or uncensored values greater than or equal to $0.05 \mu \mathrm{g} / \mathrm{L}$, the laboratory reporting level.

Pesticide compounds detected by use of GC were determined in all but 2 samples collected at fixed and synoptic sites. Pesticide degradation products detected by use of HPLC were determined in samples collected at two fixed sites (01470779, Tulpehocken Creek near Bernville, Pa., and 01474500, Schuylkill River at Philadelphia, Pa.) from March 1999 to August 2000 (fig. 4, table 1).

\section{Quality Assurance/Quality Control Methods}

Samples for QA/QC (Quality Assurance/Quality Control) were collected and analyzed to determine the bias and variability of the frequency of detection of pesticide compounds as well as the bias and variability of the concentration. Bias is the systematic error inherent in a method and can be positive or negative (Mueller and others, 1997). Positive bias indicates that the reported concentrations, in general, are greater than the concentrations actually present in the streamwater; negative bias indicates that the reported concentrations are less than those actu- ally present. Variability is the degree of random error in repeated measurements of the same quality (Mueller and others, 1997). The smaller the variability, the more likely it is that repeated measurements of a pesticide compound in a streamwater sample will result in the same concentration value.

Field blanks were collected to determine whether reported concentrations of pesticide compounds were biased high because of sample contamination. Field blanks were created for selected streamwater samples by processing water free of pesticide compounds through the equipment used for sample collection, splitting, and filtration; the blank then was sent to the laboratory for analysis for pesticide compounds.

Replicates were collected to provide information on the variability of the detection and concentration of pesticide compounds. Replicates were created for selected samples by filtering a second subsample and sending it to the laboratory for analysis for pesticide compounds.

The variability of the concentrations of pesticide compounds was determined by calculating the difference between concentrations in streamwater samples and concentrations in associated replicates by use of equation (1) given below. Nondetected concentrations were set to zero.

$$
D=100 \times A b s[(S-R) /((S+R) / 2)],
$$
where $\quad S=$ streamwater concentration, in micrograms per liter;
$R=$ replicate concentration, in micrograms per liter;
$D=$ difference, in percent of mean concentra- tion;
and

$A b s=$ absolute value of

\section{Application Rates of Pesticides to Agricultural Land}

Amounts of pesticides annually applied to agricultural land within the Delaware River Basin were determined from information in Gianessi and Marcelli (2000). For important crops in each county of the conterminous United States during 1997, Gianessi and Marcelli provide estimates of the area of cultivation as well as estimates of the annual amounts of pesticides applied per unit area of cultivation. For most crops and counties, the area of cultivation is for commercial farms; a farm is any place from which $\$ 1,000$ or more of agricultural products were produced and sold, or normally would have been sold, during 1997. For each of the pesticides most often detected in the Delaware River Basin, the amount annually applied to agricultural land within the Delaware River Basin was determined by use of the following equations: 
Table 2. Pesticides and degradation products analyzed for in streamwater in the Delaware River Basin, December 1998August 2001.

[Pesticide compounds shown in bold type were not detected; GC, gas chromatography; HPLC, high performance liquid chromatography; H, herbicide; I, insecticide; DP, degradation product; ESA, ethane sulfonic acid; OA, oxanilic acid; common or trade names are from Ebbert and Embrey (2002) and Meister Publishing Company (2000); na, not available or not applicable]

\begin{tabular}{|c|c|c|c|c|c|}
\hline \multirow{2}{*}{ Pesticide compound } & \multirow{2}{*}{$\begin{array}{l}\text { Type of compound } \\
\text { (parent pesticide of } \\
\text { degradation } \\
\text { product) }\end{array}$} & \multicolumn{2}{|c|}{$\begin{array}{l}\text { Laboratory reporting level, in } \\
\text { micrograms per liter }\end{array}$} & \multirow{2}{*}{$\begin{array}{c}\text { Common or trade } \\
\text { names }\end{array}$} & \multirow{2}{*}{$\begin{array}{c}\text { Chemical } \\
\text { Abstract Services } \\
\text { registry number }\end{array}$} \\
\hline & & $\begin{array}{l}\text { At beginning of } \\
\text { study }\end{array}$ & At end of study & & \\
\hline \multicolumn{6}{|c|}{ GC Pesticide compounds } \\
\hline Acetochlor & $\mathrm{H}$ & 0.002 & 0.0041 & Guardian & $34256-82-1$ \\
\hline Alachlor & $\mathrm{H}$ & .002 & .0024 & Lasso & $15972-60-8$ \\
\hline Atrazine & $\mathrm{H}$ & .001 & .007 & AAtrex & $1912-24-9$ \\
\hline Azinphos, methyl $^{1}$ & I & .001 & .05 & Guthion & $86-50-0$ \\
\hline Benfluralin & $\mathrm{H}$ & .002 & .01 & Balan, Benefin & $1861-40-1$ \\
\hline Butylate & $\mathrm{H}$ & .0020 & .0020 & Sutan + , Genate Plus & $2008-41-5$ \\
\hline Carbaryl $^{1}$ & I & .003 & .041 & Sevin, Savit & $63-25-2$ \\
\hline Carbofuran $^{1}$ & I & .003 & .02 & Furadan & $1563-66-2$ \\
\hline Chlorpyrifos & I & .004 & .005 & Lorsban, Dursban & $2921-88-2$ \\
\hline Cyanazine & $\mathrm{H}$ & .004 & .018 & Bladex & $21725-46-2$ \\
\hline Dacthal & $\mathrm{H}$ & .002 & .003 & Dachtal, DCPA & $1861-32-1$ \\
\hline p,p'-DDE & $\mathrm{DP}(\mathrm{DDT})$ & .006 & .0025 & na & $72-55-9$ \\
\hline Deethylatrazine $^{1}$ & DP (atrazine) & .002 & .006 & Desethyl atrazine & $6190-65-4$ \\
\hline Diazinon & I & .002 & .005 & Diazinon & $333-41-5$ \\
\hline Dieldrin & I & .001 & .0048 & Panoram D-31 & $60-57-1$ \\
\hline 2,6-Diethylaniline & DP (alachlor) & .0030 & .0017 & na & $579-66-8$ \\
\hline Disulfoton & I & .0170 & .0210 & Di-Syston & $298-04-4$ \\
\hline EPTC & $\mathrm{H}$ & .002 & .002 & Eptam, Eradicane & $759-94-4$ \\
\hline Ethalfluralin & $\mathrm{H}$ & .0040 & .0090 & Sonalan, Curbit EC & $55283-68-6$ \\
\hline Ethoprop & I & .0030 & .0050 & Ethoprophos, Mocap & $13194-48-4$ \\
\hline Fonofos & I & .0030 & .0027 & Dyfonate & $944-22-9$ \\
\hline alpha-HCH ${ }^{2}$ & DP (lindane) & .0020 & .0046 & na & $319-84-6$ \\
\hline Lindane & I & .004 & .004 & Lindane, gamma-HCH & $58-89-9$ \\
\hline Linuron & $\mathrm{H}$ & .002 & .035 & Lorox, Linex & $330-55-2$ \\
\hline Malathion & $\mathrm{I}$ & .005 & .027 & Malathion & $121-75-5$ \\
\hline Methyl parathion & I & .0060 & .0060 & Penncap-M & $298-00-0$ \\
\hline Metolachlor & $\mathrm{H}$ & .002 & .013 & Dual, Pennant & $51218-45-2$ \\
\hline Metribuzin & $\mathrm{H}$ & .004 & .006 & Lexone, Sencor & 21087-64-9 \\
\hline Molinate & $\mathrm{H}$ & .0040 & .0016 & Ordram & $2212-67-1$ \\
\hline Napropamide & $\mathrm{H}$ & .003 & .007 & Devrinol & 15299-99-7 \\
\hline Parathion & I & .0040 & .0070 & (several) & $56-38-2$ \\
\hline Pebulate & $\mathrm{H}$ & .0040 & .0016 & Tillam & $1114-71-2$ \\
\hline Pendimethalin & $\mathrm{H}$ & .004 & .01 & Prowl, Stomp & $40487-42-1$ \\
\hline Permethrin, cis & I & .0050 & .0060 & Ambush, Pounce & $54774-45-7$ \\
\hline Phorate & I & .0020 & .0110 & Thimet, Rampart & $298-02-2$ \\
\hline
\end{tabular}


Table 2. Pesticides and degradation products analyzed for in streamwater in the Delaware River Basin, December 1998August 2001.-Continued

[Pesticide compounds shown in bold type were not detected; GC, gas chromatography; HPLC, high performance liquid chromatography; H, herbicide; I, insecticide; DP, degradation product; ESA, ethane sulfonic acid; OA, oxanilic acid; common or trade names are from Ebbert and Embrey (2002) and Meister Publishing Company (2000); na, not available or not applicable]

\begin{tabular}{|c|c|c|c|c|c|}
\hline \multirow{2}{*}{ Pesticide compound } & \multirow{2}{*}{$\begin{array}{l}\text { Type of compound } \\
\text { (parent pesticide of } \\
\text { degradation } \\
\text { product) }\end{array}$} & \multicolumn{2}{|c|}{$\begin{array}{l}\text { Laboratory reporting level, in } \\
\text { micrograms per liter }\end{array}$} & \multirow{2}{*}{$\begin{array}{c}\text { Common or trade } \\
\text { names }\end{array}$} & \multirow{2}{*}{$\begin{array}{l}\text { Chemical } \\
\text { Abstract Services } \\
\text { registry number }\end{array}$} \\
\hline & & $\begin{array}{c}\text { At beginning of } \\
\text { study }\end{array}$ & At end of study & & \\
\hline \multicolumn{6}{|c|}{ GC Pesticide compounds--Continued } \\
\hline Prometon & $\mathrm{H}$ & 0.018 & 0.015 & Pramitol & $1610-18-0$ \\
\hline Propachlor & $\mathrm{H}$ & .007 & .01 & Ramrod & $1918-16-7$ \\
\hline Propanil & $\mathrm{H}$ & .004 & .011 & Stampede & $709-98-8$ \\
\hline Propargite & I & .0130 & .0230 & Comite, Omite & $2312-35-8$ \\
\hline Propyzamide & $\mathrm{H}$ & .003 & .0041 & Kerb & $23950-58-5$ \\
\hline Simazine & $\mathrm{H}$ & .005 & .011 & Aquazine, Princep & $122-34-9$ \\
\hline Tebuthiuron & $\mathrm{H}$ & .01 & .016 & Spike & $34014-18-1$ \\
\hline Terbacil $^{1}$ & $\mathrm{H}$ & .007 & .034 & Sinbar & $5902-51-2$ \\
\hline Terbufos & I & .0130 & .0170 & Counter & 13071-79-9 \\
\hline Thiobencarb & $\mathrm{H}$ & .0020 & .0048 & Bolero & $28249-77-6$ \\
\hline Triallate & $\mathrm{H}$ & .0010 & .0023 & Far-Go & $2303-17-5$ \\
\hline Trifluralin & $\mathrm{H}$ & .002 & .009 & Treflan, Trilin & $1582-09-8$ \\
\hline \multicolumn{6}{|c|}{ HPLC pesticide degradation products } \\
\hline Acetochlor ESA & DP (acetochlor) & .05 & .05 & na & na \\
\hline Acetochlor OA & DP (acetochlor) & .05 & .05 & na & na \\
\hline Alachlor ESA & DP (alachlor) & .05 & .05 & na & na \\
\hline Alachlor OA & DP (alachlor) & .05 & .05 & na & na \\
\hline Metolachlor ESA & DP (metolachlor) & .05 & .05 & na & na \\
\hline Metolachlor OA & DP (metolachlor) & .05 & .05 & na & na \\
\hline
\end{tabular}

${ }^{1}$ All detected concentrations were estimated.

${ }^{2}$ Alpha-hexachlorocyclohexane. 


$$
L_{j}=\underset{\text { crops }}{\sum_{i, j}}\left[\left(C_{i, j}\right) \times\left(P_{i, j}\right)\right],
$$

$$
\begin{aligned}
& P_{i, j}={\text { application rate for } \text { crop }_{i} \text { in county }}_{j} \text {, in } \\
& \text { pounds per square mile. }
\end{aligned}
$$

$$
T=\sum_{\text {counties }}\left[\left(B_{j} / C_{j}\right) \times\left(L_{j}\right)\right],
$$

where $T=$ total amount of selected pesticide applied to study area, in pounds;

$B_{j}=$ area of county $_{j}$ in Delaware River Basin, in square miles;

and

$C_{j}=$ area of county ${ }_{j}$, in square miles;

$L_{j} \quad=$ total annual application of selected pesticide to county ${ }_{j}$, in pounds.

The amount of each pesticide annually applied to the drainage basins of selected sites was calculated by use of the equation

$$
A=\left[\sum_{\text {counties }}\left[\left(F_{j} / C_{j}\right) \times L_{j}\right]\right] / D,
$$

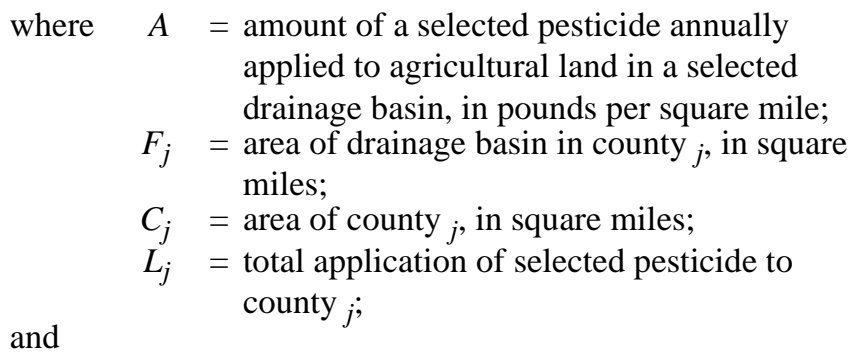

$D=$ area of drainage basin, in square miles.

\section{Methods of Data Analysis}

The probability plot method (Helsel and Cohn, 1988) was used to determine the median concentration of each pesticide compound in all samples. Estimated values were treated as uncensored values. Medians less than the laboratory reporting level were displayed as nondetected.

Kendall's tau (Helsel and Hirsh, 1992) was used to identify relations among pesticide concentrations and streamflow, streamwater turbidity, land use, population density, or the rate of pesticide application to agricultural land. Relations were considered to be present at a 0.05 level of significance. Estimated values were assumed to be equivalent to uncensored values, and nondetected values were set to zero.

LOWESS smoothed curves (described in Helsel and Hirsh, 1992) are shown in figures to provide a visual indication of some relations identified by Kendall's tau. In some figures, nondetected concentrations are plotted at values of $0.001 \mu \mathrm{g} / \mathrm{L}$.

\section{Pesticide Compounds in Streamwater in the Delaware River Basin}

\section{Summary of Detection Frequencies and Concentrations}

A summary of the frequencies of detection for each pesticide compound in all streamwater samples is given in table 3. Maximum laboratory reporting levels and median and maximum concentrations also are shown. Compounds not detected are shown in bold in table 2 .

\section{Pesticide Compounds (Gas Chromatography)}

A total of 531 samples were collected at 94 sites in the study area for analysis for these pesticide compounds. Of this total, 361 samples were collected at the 10 fixed sites under base-flow and stormflow conditions, and 170 were collected under base-flow conditions at synoptic sites.

At least one pesticide compound was detected in 95 percent of samples. The median number of compounds detected in a sample was 6 , and the maximum number was 15 .

Of the 47 pesticide compounds analyzed for, 30 were detected (table 3). Fourteen pesticide compounds-10 herbicides, 3 insecticides, and 1 degradation product - were detected in 8 percent or more of samples (fig. 6). Atrazine, metolachlor, deethylatrazine, and simazine were the compounds most often detected.

The variation of maximum laboratory reporting level ( 0.002 to 0.05 microgram per liter) does not appear to be the reason that these compounds were the most often detected. These compounds also were the most often detected of those with concentrations greater than or equal to $0.05 \mu \mathrm{g} / \mathrm{L}$, the value 
Table 3. Summary of the frequencies of detection and the concentrations of pesticide compounds detected in streamwater in the Delaware River Basin, December 1998August 2001.

[GC, gas chromatography; HPLC, high performance liquid chromatography; H, herbicide; I, insecticide; DP, degradation product; sources of standards and guidelines are described in table 8; E, estimated; <, less than; ESA, ethane sulfonic acid; OA, oxanilic acid; --, not available or not applicable]

\begin{tabular}{|c|c|c|c|c|c|c|c|c|c|c|}
\hline \multirow[b]{2}{*}{$\begin{array}{l}\text { Pesticide } \\
\text { compound }\end{array}$} & \multirow[b]{2}{*}{$\begin{array}{l}\text { Type of pesticide } \\
\text { compound } \\
\text { (parent pesticide } \\
\text { of degradation } \\
\text { product) }\end{array}$} & \multicolumn{2}{|c|}{$\begin{array}{l}\text { Frequency of detection, in } \\
\text { percent of all samples }\end{array}$} & \multirow[b]{2}{*}{$\begin{array}{l}\text { Laboratory } \\
\text { reporting } \\
\text { level, in } \\
\text { micrograms } \\
\text { per liter } \\
\text { (maximum } \\
\text { during period } \\
\text { of study) }\end{array}$} & \multicolumn{2}{|c|}{$\begin{array}{l}\text { Concentration, in } \\
\text { micrograms per liter }\end{array}$} & \multicolumn{2}{|c|}{$\begin{array}{c}\text { Drinking-water standard or } \\
\text { guideline }\end{array}$} & \multicolumn{2}{|c|}{ Aquatic-life guideline } \\
\hline & & $\begin{array}{c}\text { Of all } \\
\text { concen- } \\
\text { trations }\end{array}$ & $\begin{array}{c}\text { Of } \\
\text { concentrations } \\
\text { greater than or } \\
\text { equal to } \\
0.05 \text { milligram } \\
\text { per liter }\end{array}$ & & Median & Maximum & $\begin{array}{c}\text { Value, in } \\
\text { micrograms } \\
\text { per liter }\end{array}$ & $\begin{array}{l}\text { Number of } \\
\text { samples in } \\
\text { which } \\
\text { concentration } \\
\text { exceeded } \\
\text { standard or } \\
\text { guideline }\end{array}$ & $\begin{array}{c}\text { Value, in } \\
\text { micrograms } \\
\text { per liter }\end{array}$ & $\begin{array}{c}\text { Number of } \\
\text { samples in } \\
\text { which } \\
\text { concen- } \\
\text { tration } \\
\text { exceeded } \\
\text { guideline }\end{array}$ \\
\hline \multicolumn{11}{|c|}{ GC pesticide compounds detected in 531 streamwater samples at all sites } \\
\hline Acetochlor & $\mathrm{H}$ & 9.8 & 0.9 & 0.0041 & $<0.0041$ & 0.36 & -- & -- & -- & -- \\
\hline Alachlor & $\mathrm{H}$ & 11.1 & .4 & .0024 & $<.0024$ & .074 & 2 & 0 & -- & -- \\
\hline Atrazine & $\mathrm{H}$ & 90.2 & 29.2 & .007 & .021 & E 4.9 & 3 & 1 & 1.8 & 2 \\
\hline Azinphos, methyl ${ }^{1}$ & I & 1.5 & 0 & .05 & $<.05$ & Е.027 & 20 & 0 & .01 & 6 \\
\hline Benfluralin & $\mathrm{H}$ & 5.1 & .2 & .01 & $<.01$ & E.071 & -- & -- & -- & -- \\
\hline Carbaryl $^{1}$ & I & 33 & 6.2 & .041 & $<.041$ & E 2.4 & 700 & 0 & .2 & 7 \\
\hline Carbofuran $^{1}$ & I & 1.5 & .2 & .02 & $<.02$ & E.11 & 40 & 0 & 1.8 & 0 \\
\hline Chlorpyrifos & I & 11.1 & .2 & .005 & $<.005$ & .051 & 20 & 0 & .041 & 1 \\
\hline Cyanazine & $\mathrm{H}$ & 9.6 & 1.1 & .018 & $<.018$ & .48 & 1 & 0 & 2 & 0 \\
\hline Dacthal & $\mathrm{H}$ & 7.7 & 0 & .003 & $<.003$ & .015 & 70 & 0 & -- & -- \\
\hline p,p'-DDE & $\mathrm{DP}$ (DDT) & 5.8 & 0 & .006 & $<.006$ & E.004 & 1 & 0 & .001 & 30 \\
\hline Deethylatrazine $^{1}$ & DP (atrazine) & 82.5 & 20 & .006 & .02 & E. 3 & -- & -- & -- & -- \\
\hline Diazinon & I & 34.6 & 5.9 & .005 & $<.005$ & .47 & .6 & 0 & .08 & 19 \\
\hline Dieldrin & I & 2.1 & 0 & .0048 & $<.0048$ & .033 & .02 & 5 & .056 & 0 \\
\hline ЕРТC & $\mathrm{H}$ & 1.7 & 0 & .002 & $<.002$ & .016 & -- & -- & -- & -- \\
\hline Lindane & I & .9 & 0 & .004 & $<.004$ & .015 & 0.2 & 0 & .01 & 2 \\
\hline Linuron & $\mathrm{H}$ & .6 & .6 & .035 & $<.035$ & .509 & -- & -- & 7 & 0 \\
\hline Malathion & I & 2.6 & .2 & .027 & $<.027$ & .055 & 100 & 0 & .1 & 0 \\
\hline Metolachlor & $\mathrm{H}$ & 86.1 & 15.4 & .013 & .013 & 1.3 & 100 & 0 & 7.8 & 0 \\
\hline Metribuzin & $\mathrm{H}$ & 1.7 & .2 & .006 & $<.006$ & .10 & 200 & 0 & 1 & 0 \\
\hline Napropamide & $\mathrm{H}$ & 1.7 & 0 & 0.007 & $<0.007$ & 0.014 & -- & -- & -- & -- \\
\hline
\end{tabular}


Table 3. Summary of the frequencies of detection and the concentrations of pesticide compounds detected in streamwater in the Delaware River Basin, December 1998August 2001.-Continued

[GC, gas chromatography; HPLC, high performance liquid chromatography; H, herbicide; I, insecticide; DP, degradation product; sources of standards and guidelines are described in table 8; E, estimated; <, less than; ESA, ethane sulfonic acid; OA, oxanilic acid; --, not available or not applicable]

\begin{tabular}{|c|c|c|c|c|c|c|c|c|c|c|}
\hline \multirow[b]{2}{*}{$\begin{array}{l}\text { Pesticide } \\
\text { compound }\end{array}$} & \multirow[b]{2}{*}{$\begin{array}{l}\text { Type of pesticide } \\
\text { compound } \\
\text { (parent pesticide } \\
\text { of degradation } \\
\text { product) }\end{array}$} & \multicolumn{2}{|c|}{$\begin{array}{l}\text { Frequency of detection, in } \\
\text { percent of all samples }\end{array}$} & \multirow{2}{*}{$\begin{array}{c}\text { Laboratory } \\
\text { reporting } \\
\text { level, in } \\
\text { micrograms } \\
\text { per liter } \\
\text { (maximum } \\
\text { during period } \\
\text { of study) }\end{array}$} & \multicolumn{2}{|c|}{$\begin{array}{l}\text { Concentration, in } \\
\text { micrograms per liter }\end{array}$} & \multicolumn{2}{|c|}{$\begin{array}{c}\text { Drinking-water standard or } \\
\text { guideline }\end{array}$} & \multicolumn{2}{|c|}{ Aquatic-life guideline } \\
\hline & & $\begin{array}{l}\text { Of all } \\
\text { concen- } \\
\text { trations }\end{array}$ & $\begin{array}{c}\text { Of } \\
\text { concentrations } \\
\text { greater than or } \\
\text { equal to } \\
0.05 \text { milligram } \\
\text { per liter }\end{array}$ & & Median & Maximum & $\begin{array}{c}\text { Value, in } \\
\text { micrograms } \\
\text { per liter }\end{array}$ & $\begin{array}{l}\text { Number of } \\
\text { samples in } \\
\text { which } \\
\text { concentration } \\
\text { exceeded } \\
\text { standard or } \\
\text { guideline }\end{array}$ & $\begin{array}{c}\text { Value, in } \\
\text { micrograms } \\
\text { per liter }\end{array}$ & $\begin{array}{c}\text { Number of } \\
\text { samples in } \\
\text { which } \\
\text { concen- } \\
\text { tration } \\
\text { exceeded } \\
\text { guideline }\end{array}$ \\
\hline \multicolumn{11}{|c|}{ GC pesticide compounds detected in 531 streamwater samples at all sites--Continued } \\
\hline Pendimethalin & $\mathrm{H}$ & 10.9 & 0.9 & .01 & $<.01$ & .12 & -- & -- & -- & -- \\
\hline Prometon & $\mathrm{H}$ & 58.8 & 4.7 & .018 & $<.018$ & 2.0 & 100 & 0 & -- & -- \\
\hline Pronamide & $\mathrm{H}$ & .8 & 0 & .0041 & $<.0041$ & .015 & 50 & 0 & -- & -- \\
\hline Propachlor & $\mathrm{H}$ & .4 & 0 & .01 & $<.01$ & E.0052 & 90 & 0 & -- & -- \\
\hline Propanil & $\mathrm{H}$ & .2 & 0 & .011 & $<.011$ & .0088 & -- & -- & -- & -- \\
\hline Simazine & $\mathrm{H}$ & 78.9 & 9.2 & .011 & .011 & 9.4 & 4 & 1 & 10 & 0 \\
\hline Tebuthiuron & $\mathrm{H}$ & 20.3 & 0 & .016 & $<.016$ & .039 & 500 & 0 & 1.6 & 0 \\
\hline Terbacil $^{1}$ & $\mathrm{H}$ & 6.2 & 4.5 & .034 & $<.034$ & E.19 & 90 & 0 & -- & -- \\
\hline Trifluralin & $\mathrm{H}$ & 12.1 & 0 & .009 & $<.009$ & .011 & 5 & 0 & .2 & 0 \\
\hline \multicolumn{11}{|c|}{ HPLC pesticide degradation products detected in 70 streamwater samples at two fixed sites } \\
\hline Acetochlor ESA & DP (acetochlor) & 8.6 & 8.6 & .05 & $<.05$ & .28 & -- & -- & -- & -- \\
\hline Acetochlor OA & DP (acetochlor) & 2.9 & 2.9 & .05 & $<.05$ & .06 & -- & -- & -- & -- \\
\hline Alachlor ESA & DP (alachlor) & 80 & 80 & .05 & .145 & 1.05 & -- & -- & -- & -- \\
\hline Metolachlor ESA & DP (metolachlor) & 98.6 & 98.6 & .05 & .51 & 1.65 & -- & -- & -- & -- \\
\hline Metolachlor OA & DP (metolachlor) & 55.7 & 55.7 & .05 & .06 & .37 & -- & -- & -- & \\
\hline
\end{tabular}




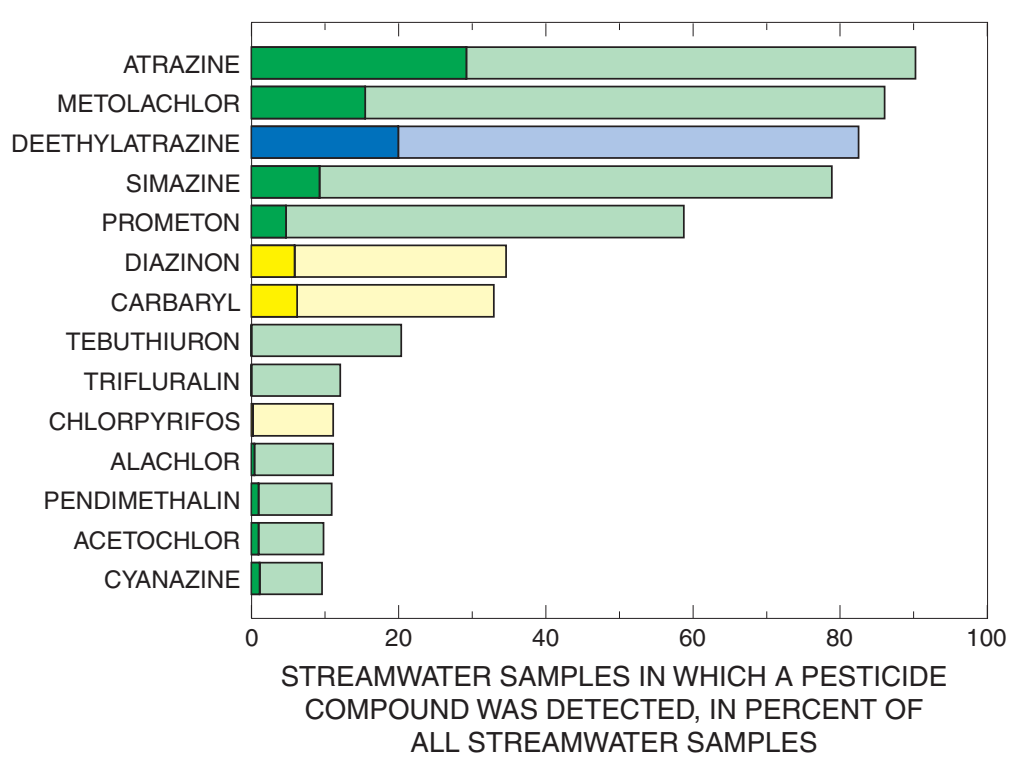

\section{EXPLANATION}

Herbicide concentration greater than or equal to 0.05 microgram per liter

Herbicide concentration detected at less than 0.05 microgram per liter

Insecticide concentration greater than or equal to 0.05 microgram per liter

Insecticide concentration detected at less than 0.05 microgram per liter

Degradation product concentration greater than or equal to 0.05 microgram per liter

Degradation product concentration detected at less than 0.05 microgram per liter

Figure 6. Frequences of detection of the pesticide compounds most often detected in 531 samples of streamwater by use of gas chromatography, Delaware River Basin, December 1998-August 2001. (Compounds were detected in at least 8 percent of samples.)

of the greatest maximum laboratory reporting levels for detected compounds (table 3, fig. 6). Unless stated otherwise in this report, detection frequencies include all detected concentrations.

The pesticide compounds most frequently detected in streamwater samples from the Delaware River Basin (fig. 6; table 3) are among the compounds most frequently detected by other NAWQA studies in streamwater samples throughout the Nation and in the Northeast. These compounds were among the most frequently detected in samples from 50 streamwater sites nationwide (Larson and others, 1999). Atrazine, metolachlor, prometon, simazine, and deethylatrazine were the compounds most frequently detected in samples from 50 streams in New York and New Jersey (Reiser and O'Brien, 1999) and in samples from 46 streams of the Hudson River Basin (Wall and others, 1998). In streamwater of the Lower Susquehanna River Basin, atrazine and metolachlor were the most frequently detected herbicides, and diazinon and carbaryl were the most frequently detected insecticides (Lindsey and others, 1998).

\section{Pesticide Degradation Products (High Performance Liquid Chromatography)}

Of the 6 pesticide degradation products analyzed for in 70 samples from 2 sites, 5 were detected (table 3 ); alachlor OA was the only compound not detected (table 2 ). At least one degradation product was detected in 69 of 70 samples; the median number of degradation products detected was 2 and the maximum number was 5 . The most often detected degradation product was metolachlor ESA (98.6 percent of samples).
ESA and OA degradation products of alachlor, acetochlor, or metolachlor have been detected in streams in the Midwest (Kalkhoff and others, 1998; Kalkhoff and others, 2003) and in New York State (Phillips and others, 1999). Most of these streams drain basins with agricultural land use.

\section{Bias and Variability of Detection Frequencies and Concentrations}

Bias and variability in reported concentrations of the pesticide compounds were determined from (1) examination of the results of analysis of QA/QC samples, (2) comparison of these results with results of analysis of streamwater samples, and (3) evaluation of results of analyses of QA/QC samples from previous NAWQA studies (Martin, 2002; Martin and others, 1999). These previous studies may not represent current conditions because of changes in laboratory reporting procedures in 1999 (Oblinger Childress and others, 1999) and annual reassessment of the laboratory reporting levels since then.

\section{Pesticide Compounds (Gas Chromatography)}

Evaluations of results of analysis of the 16 field blanks indicated that, of the $47 \mathrm{GC}$ pesticide compounds, the analytical results of only p,p'-DDE were biased because of sample contamination. p,p'-DDE was the only pesticide compound detected in any of the 16 field blanks; it was detected in one blank. Comparison of the detection frequencies in streamwater samples and field blanks also supports this hypothesis; the 
frequency of detection of p,p'-DDE in field blanks (6.3 percent) is close to the frequency of detection in all streamwater samples (5.8 percent), which would be expected if detections resulted because of sample contamination only. From an evaluation of results of analyses of field blanks and streamwater samples for pesticide compounds in previous NAWQA studies, Martin and others (1999) concluded that p,p'-DDE was one of the pesticide compounds for which contamination should be considered when interpreting its detection in streamwater samples.

The variability of detections and concentrations of GC pesticide compounds in streamwater samples was determined by comparing detections and concentrations in 14 replicate samples to corresponding values in the associated streamwater samples. For the purpose of this comparison, there were considered to be 658 pairs of concentrations ( 47 compounds in 14 samples); each pair included one value from the replicate sample and one from the streamwater sample.

For this study, the variability of analyte detection is defined as the ratio of the pairs of values with inconsistent results to the pairs of values with at least one detection. Inconsistent results were present for the pairs of values in which the analyte was detected in one value of the pair but not the other.

The variability of detection was calculated to be 9.7 percent on the basis of the 10 pairs of values with inconsistent results and the 103 pairs of values with at least one detection. This result is an estimate of the overall variability of all the GC pesticide compounds detected.

This variability of detections of pesticide compounds is within the range of corresponding values calculated from results reported by Martin (2002). Martin compared detections of compounds in environmental samples (both ground water and streamwater) collected by the NAWQA Program during 1992-97 to detections in associated replicates; in some cases, there was more than one replicate for an environmental sample. Martin noted that (1) variability of detections of pesticide compounds was greatest when the compound concentration was small, and (2) variability decreased with increasing concentration. For samples/replicates with the smallest concentrations, a variability of 37 percent was calculated (for GC pesticide compounds in Martin, 2002, table 4). For samples with the largest concentrations, a variability of 0.7 percent was calculated (GC pesticide compounds in Martin, 2002, table 6). Martin attributed this variability of detection to variability of the laboratory method and to matrix interferences (or other processes) that result in false-negative errors. Matrix interference is the effect of the presence of compounds not being analyzed for on the results of the laboratory analysis.

An estimate of the variability of concentration of pesticide compounds was calculated as the median of the differences between concentrations in streamwater samples and concentrations in replicates by use of equation 1 . Only the 103 pairs of values with at least one detected value were included. Nondetected values were set to zero.

By the definition described above, the variability of concentrations appears to be small; the median difference between concentrations in replicates and concentrations in streamwater samples was 4.5 percent of the mean concentration; 95 percent of the differences were within 36 percent. These results are a gross estimate of the variability of all concentrations of all detected analytes but most accurately reflect the variability of compounds most often detected (atrazine and metolachlor, for example).

The median difference ( 4.5 percent) is within the range of typical median differences reported by Martin (2002, table 8) when nondetected values were set to zero. Martin determined differences in concentrations of pesticides and degradation products in streamwater and replicate samples analyzed as part of previous NAWQA studies.

\section{Pesticide Degradation Products (High Performance Liquid Chromatography)}

Bias because of sample contamination does not appear to be important. In the five blanks analyzed for the six degradation products, none were detected.

\section{Relations Between Concentrations of Selected Pesticides and Indicators of Agricultural and Nonagricultural Uses of Pesticides}

Although pesticides traditionally have been associated with agricultural uses, many of the pesticides identified in the Delaware River Basin appear to have both agricultural and nonagricultural uses (table 4). A summary of nationwide uses is given in table 4, which could include uses not present in the study area. For this report, agricultural uses consist of the application of pesticides to agricultural land, and nonagricultural uses consist of the application of pesticides to buildings (including residences) and nonagricultural land such as lawns, roadways, and woodlands.

The relation between frequency of detection in all streamwater samples and the estimated amount applied to agricultural land in the Delaware River Basin (fig. 7) indicates that agricultural uses could be important sources of some pesticides and nonagricultural uses could be important sources of others. Agricultural uses could be important sources of atrazine and metolachlor; these pesticides are applied most heavily to agricultural land and are detected most often in streamwater. Nonagricultural uses probably are important for prometon and tebuthiuron. Prometon has no agricultural uses, and the estimated application of tebuthiuron to agricultural land in the basin was zero. Other factors, such as how quickly a pesticide breaks down to its degradation products, also can determine the relation between the amount applied for agricultural uses and the frequency of detection in streamwater.

Whether (1) agricultural uses appeared to be more important than nonagricultural uses or (2) nonagricultural uses appeared to be more important than agricultural uses was determined by identifying relations between pesticide concentrations at selected sites and characteristics of the subbasins associated with the sites. The pesticides included in this analysis were 
Table 4. Selected nationwide uses of pesticides detected most often in streamwater in the Delaware River Basin, December 1998August 2001.

[Pesticides were detected in 8 percent or more of samples; H, herbicide; I, insecticide; --, uses not reported or found; USEPA, U.S. Environmental Protection Agency]

\begin{tabular}{|c|c|c|c|}
\hline \multirow[b]{2}{*}{ Pesticide } & \multirow{2}{*}{$\begin{array}{c}\text { Type of } \\
\text { pesticide }\end{array}$} & \multicolumn{2}{|r|}{ Selected nationwide uses } \\
\hline & & $\begin{array}{c}\text { Agricultural } \\
\text { (Thelin and Gianessi, 2000) }\end{array}$ & Nonagricultural \\
\hline Alachlor & $\mathrm{H}$ & Corn, soybeans, sweet corn & -- (USEPA, 1998) \\
\hline Atrazine & $\mathrm{H}$ & Corn, pasture, sweet corn & Woodlands, lawns, parks, and golf courses (USEPA, 2002a) \\
\hline $\begin{array}{l}\text { Cyanazine (sales cancelled } \\
\text { in 1999) (USEPA, undated) }\end{array}$ & $\mathrm{H}$ & Corn, sweet corn & -- \\
\hline Diazinon & I & Peaches, sweet corn, apples & $\begin{array}{l}\text { Structures, including residences, and lawns and gardens } \\
\text { (USEPA, 2001) }\end{array}$ \\
\hline Prometon & $\mathrm{H}$ & -- & Roads, railways, fence lines (Capel and others, 1999) \\
\hline Simazine & $\mathrm{H}$ & Corn, alfalfa, apples, peaches & $\begin{array}{l}\text { Golf courses, lawns, industrial sites (Meister Publishing } \\
\text { Company, 2000) }\end{array}$ \\
\hline Tebuthiuron & $\mathrm{H}$ & Pasture & $\begin{array}{l}\text { Industrial sites, rights of way, roadways, and sidewalks } \\
\text { (USEPA, 1994) }\end{array}$ \\
\hline Trifluralin & $\mathrm{H}$ & Soybeans, alfalfa, wheat & Residential uses (USEPA, 1996) \\
\hline
\end{tabular}

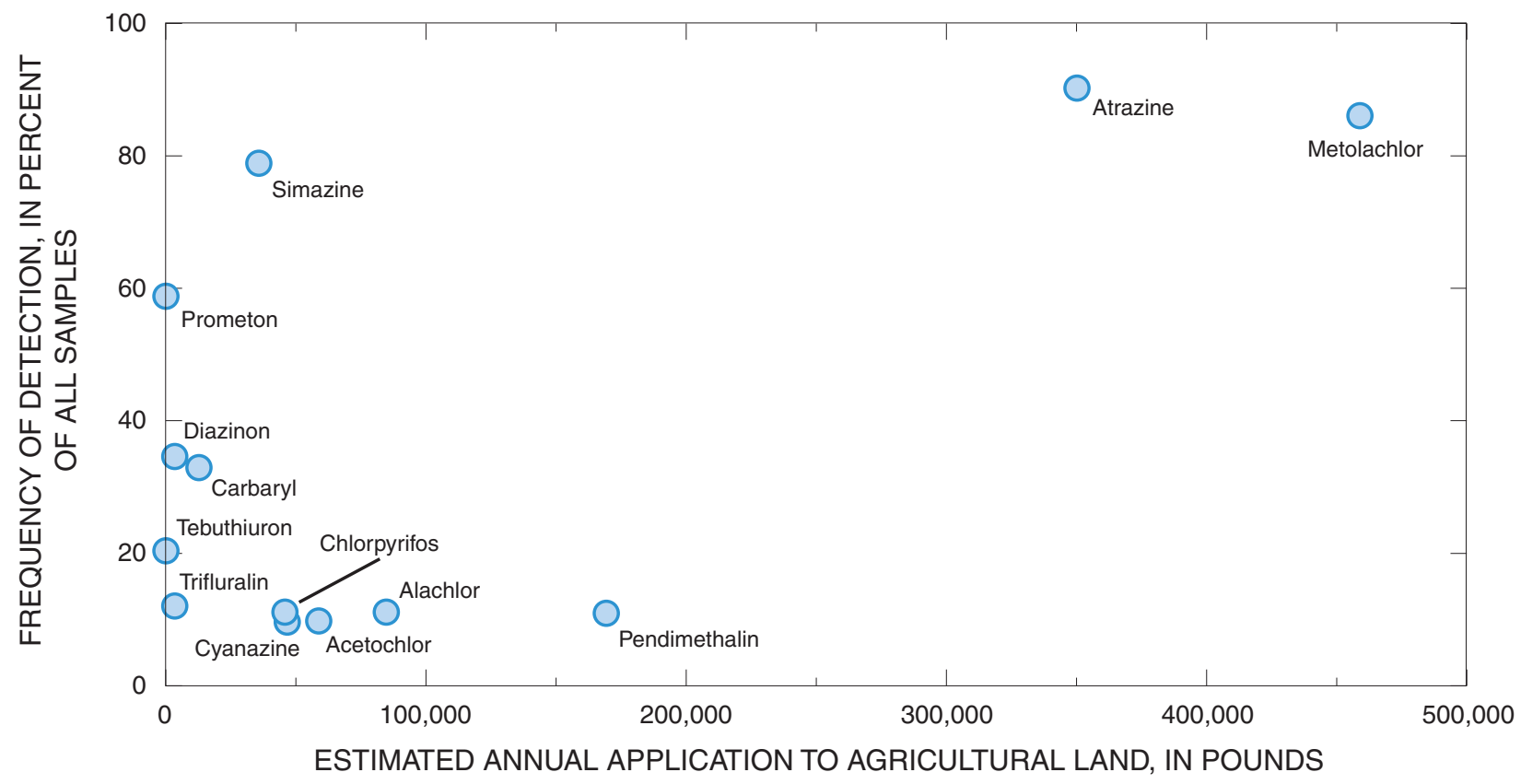

Figure 7. Relation of frequency of detection to estimated annual application to agricultural land within the Delaware River Basin. (Only pesticides detected in 8 percent or more of streamwater samples by use of gas chromatography are included.) 


\section{Pesticide Compounds in Streamwater in the Delaware River Basin, December 1998-August 2001}

those detected in 8 percent or more of all samples. The concentrations included in this analysis were those collected under base-flow conditions at synoptic sites (1) in the Piedmont and the Valley and Ridge Provinces during May and June 2000 and (2) in the Piedmont Province during August and September 2000.

The following subbasin characteristics were assumed to be indicative of the relative amount of each pesticide used for agricultural purposes in a subbasin: (1) the rate of application to agricultural land in the subbasin (in pounds per year per square mile of subbasin) as estimated from information in Gianessi and Marcelli (2000) and (2) the percentage of the subbasin composed of agricultural land (table 1). Agricultural applications are considered to be important sources for those pesticides, the concentrations of which increased with increasing values of either characteristic.

The concentrations of three pesticides (atrazine, metolachlor, and pendimethalin) increased with an increase in either the agricultural application rate or the percentage of subbasin composed of agricultural land (table 5); the relation of concentration to agricultural application rate showed nearly the same results as that to the percentage of subbasin composed of agricultural land. Relations in the spring were more likely to indicate an increase in concentrations with an increase in agricultural land than were relations in the late summer, possibly reflecting the application of pesticides in the spring.

As an example, the relation between (1) atrazine concentrations in the spring and (2) the percentage of agricultural land in the subbasin is presented in figure 8 . When all sites are considered, concentrations increase with increasing percentage of agricultural land in the subbasin. Concentrations measured in samples from sites on streams draining subbasins composed of little agricultural land (less than 20 percent) and a substantial amount of urban land (30 percent or more) do not appear to increase with increases in agricultural land, indicating that nonagricultural sources also may be important in predominantly urban subbasins.

From this analysis, agricultural uses appear to be more important sources of atrazine, metolachlor, and pendimethalin in streamwater than nonagricultural uses. The importance of agricultural uses tends to be supported by estimates of application rates to agricultural land; of the pesticides included in this analysis, atrazine, metolachlor, and pendimethalin are the most heavily applied to agricultural land (table 5). All three are used on corn and soybeans, major crops in the Delaware River Basin. Results for atrazine and metolachlor also agree with results from Larson and others (1999), who reported that atrazine and metolachlor were the pesticides most often detected in streamwater leaving agricultural basins throughout the Nation (Larson and others, 1999, fig. 14).

For atrazine, the areal variation in concentrations in streamwater throughout the Delaware River Basin also supports the importance of agricultural applications as appreciable sources to the streams. Most of the greatest concentrations during May to June during 1999, 2000, or 2001 were in samples from sites in counties with the largest estimated application per unit area of county (fig. 9). These concentrations were collected under base-flow conditions at sites with a subbasin less than or equal to $250 \mathrm{mi}^{2}$.

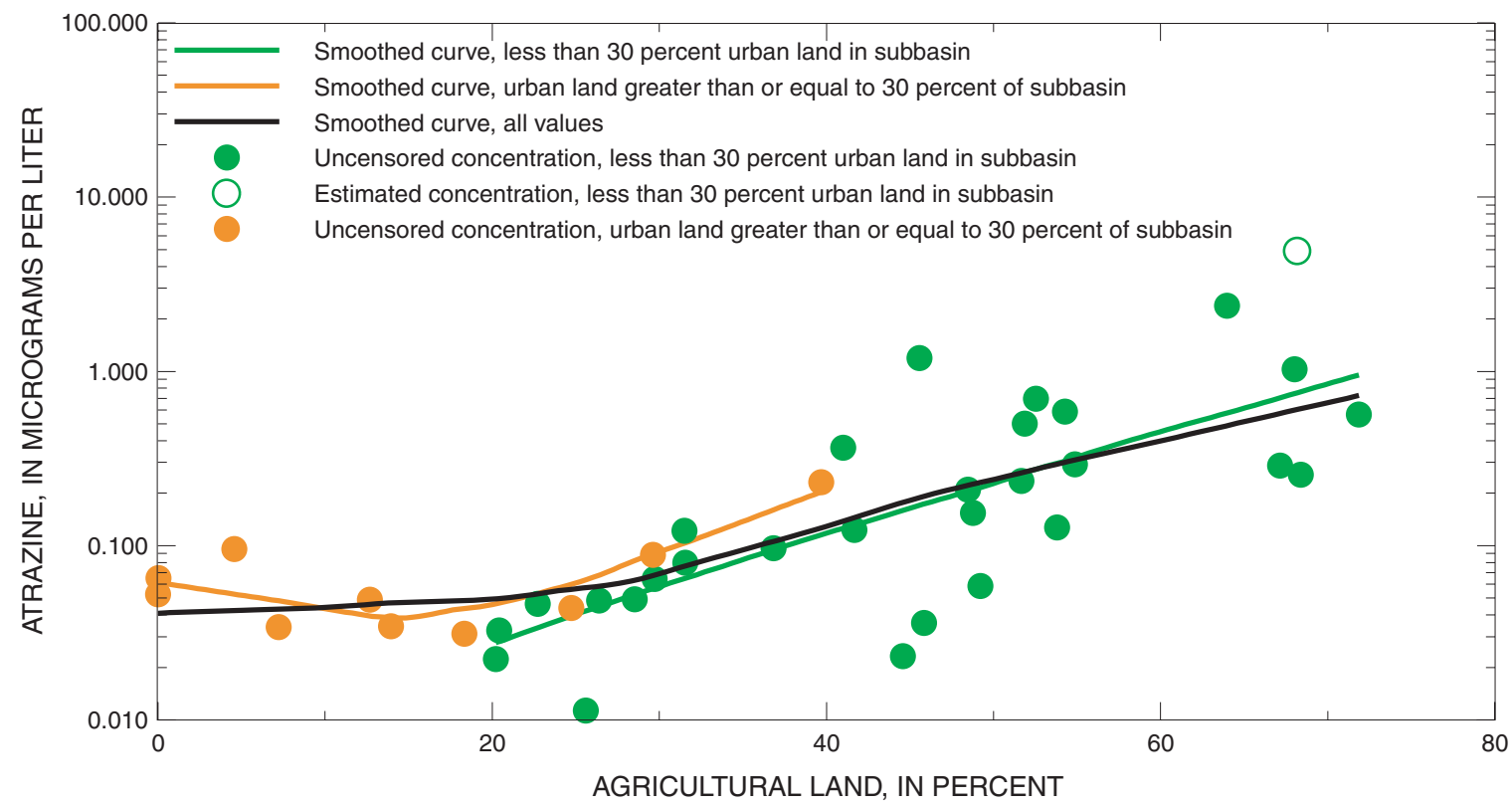

Figure 8. Relation of concentration of atrazine in streamwater to percentage of agricultural land in subbasins of the Delaware River Basin, May and June 2000. (Streamwater samples were collected during base-flow conditions at synoptic sites.) 
Table 5. Relations of concentrations of selected pesticides in streamwater to rate of application to agricultural land, and relations of concentrations of selected pesticides to percentage of agricultural land in subbasins of the Delaware River Basin, 2000.

[For pesticides in bold type, at least one relation indicated that concentrations increased with an increase in either rate of pesticide application to agricultural land or to in an increase in percentage of agricultural land in subbasin; Increased, pesticide concentrations increased with an increase in rate of application or percentage of agricultural land in subbasin; Decreased, pesticide concentrations decreased with an increase in values of rate of application or percentage of agricultural land in subbasin; Not tested, relations were not evaluated; --, concentrations did not increase or decrease. Samples were collected at sites in the Piedmont and Valley and Ridge Provinces during base-flow conditions. Relations were identified by use of Kendall's tau at a 0.05 level of significance.]

\begin{tabular}{|c|c|c|c|c|c|c|}
\hline \multirow[b]{2}{*}{ Pesticide } & \multirow{2}{*}{$\begin{array}{l}\text { Frequency of } \\
\text { detection, in } \\
\text { percent of all } \\
\text { streamwater } \\
\text { samples }\end{array}$} & \multirow[b]{2}{*}{$\begin{array}{l}\text { Amount applied to } \\
\text { agricultural land in the } \\
\text { Delaware River Basin, } \\
\text { in pounds per year }\end{array}$} & \multicolumn{2}{|c|}{$\begin{array}{c}\text { Concentrations in samples collected during } \\
\text { May-June } 2000 \\
\text { (1 sample at each of } 40 \text { sites) }\end{array}$} & \multicolumn{2}{|c|}{$\begin{array}{c}\text { Concentrations in samples collected during } \\
\text { August-September } 2000 \\
\text { (1 sample at each of } 30 \text { sites) }\end{array}$} \\
\hline & & & $\begin{array}{c}\text { Relations of } \\
\text { concentrations to an } \\
\text { increase in rate of } \\
\text { pesticide application to } \\
\text { agricultural land in } \\
\text { subbasin }\end{array}$ & $\begin{array}{c}\text { Relations of } \\
\text { concentrations to an } \\
\text { increase in percentage of } \\
\text { agricultural land in } \\
\text { subbasin }\end{array}$ & $\begin{array}{c}\text { Relations of } \\
\text { concentrations to an } \\
\text { increase in rate of } \\
\text { pesticide application to } \\
\text { agricultural land in } \\
\text { subbasin }\end{array}$ & $\begin{array}{c}\text { Relations of } \\
\text { concentrations to an } \\
\text { increase in percentage of } \\
\text { agricultural land in } \\
\text { subbasin }\end{array}$ \\
\hline Atrazine & 90.2 & 350,000 & Increased & Increased & -- & Increased \\
\hline Metolachlor & 86.1 & 460,000 & Increased & Increased & -- & -- \\
\hline Simazine & 78.9 & 36,000 & -- & -- & -- & -- \\
\hline Prometon & 58.8 & 0 & Not tested & -- & Not tested & Decreased \\
\hline Diazinon & 34.6 & 3,000 & Decreased & Decreased & -- & Decreased \\
\hline Carbaryl & 33.0 & 13,000 & Decreased & Decreased & -- & -- \\
\hline Tebuthiuron & 20.3 & 0 & Not tested & -- & Not tested & Decreased \\
\hline Trifluralin & 12.0 & 3,000 & -- & Decreased & -- & -- \\
\hline Chlorpyrifos & 11.1 & 46,000 & -- & -- & -- & Decreased \\
\hline Alachlor & 11.1 & 85,000 & -- & -- & -- & -- \\
\hline Pendimethalin & 10.9 & 170,000 & Increased & Increased & -- & -- \\
\hline Acetochlor & 9.8 & 59,000 & -- & -- & -- & -- \\
\hline Cyanazine & 9.6 & 47,000 & -- & -- & -- & -- \\
\hline
\end{tabular}




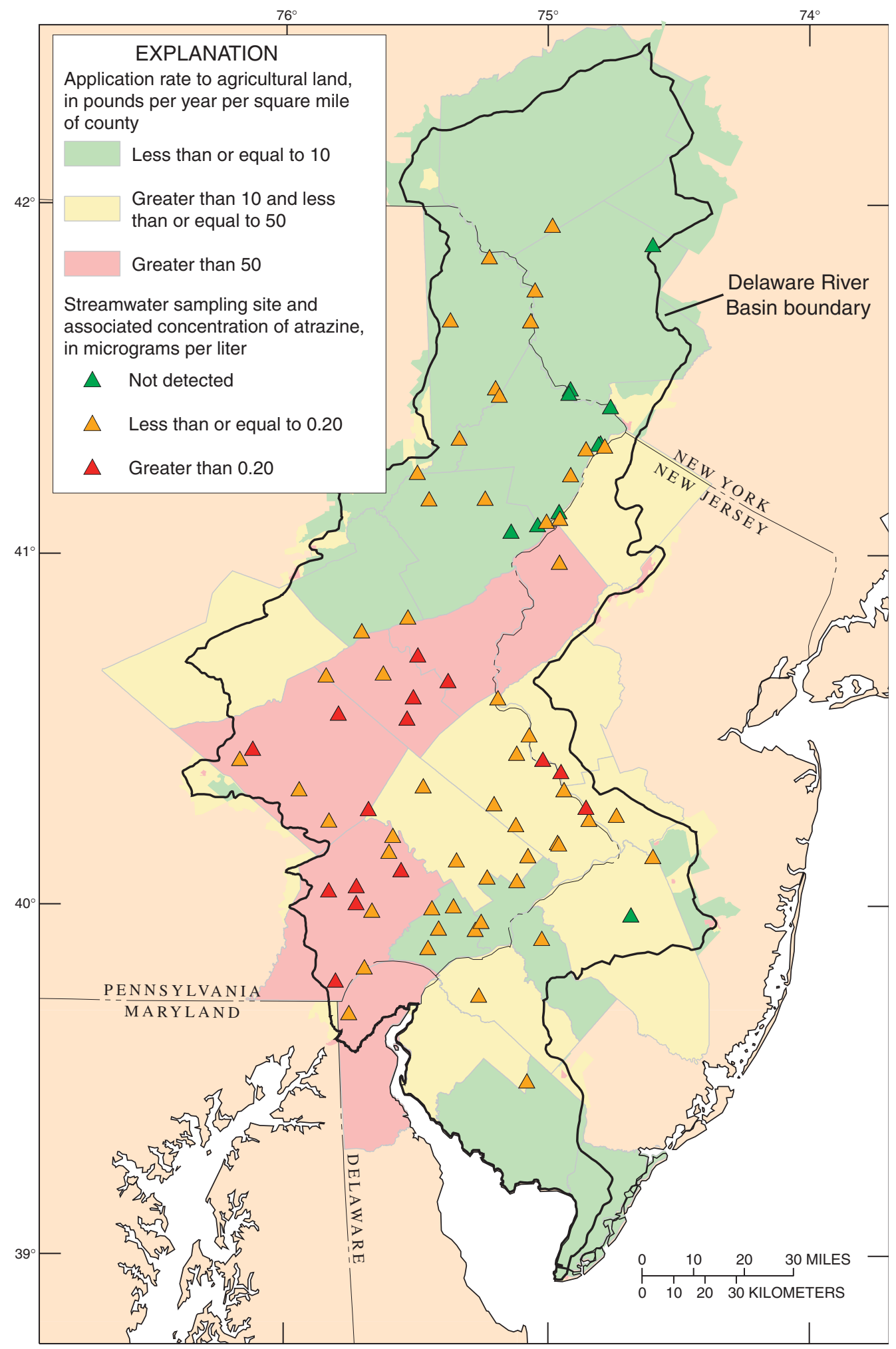

Figure 9. Streamwater sampling sites and association of atrazine under base-flow conditions, and application rates, Delaware River Basin, May and June 1999-2001. 
The following subbasin characteristics were assumed to be representative of nonagricultural uses of pesticides: (1) the percentage of the subbasin composed of urban land and (2) the population density of the subbasin in 2000. Nonagricultural uses are considered to be important sources for those pesticides, the concentrations of which increased with increasing values of either characteristic.

Concentrations of six pesticides increased with increasing values of either population density or the percentage of subbasin composed of urban land (table 6); relations between concentrations and population density showed nearly the same results as the relations between concentrations and the percentage of subbasin composed of urban land. An example of one relation is shown in figure 10. Relations for spring were different than relations for late summer. For example, concentrations for carbaryl and trifluralin in the spring increased with these basin characteristics, but concentrations in the late summer did not; on the other hand, concentrations of chlorpyrifos in the late summer increased with the basin characteristics, but concentrations in the spring did not.

Relations between concentrations and subbasin characteristics indicate that nonagricultural uses appear to be more important than agricultural uses for prometon, diazinon, carbaryl, tebuthiuron, trifluralin, and chlorpyrifos (table 6). Of these six, prometon and tebuthiuron have no reported agricultural uses in the Delaware River Basin. Diazinon, carbaryl, trifluralin, and chlorpyrifos do have agricultural uses, but appar- ently, the nonagricultural uses require greater quantities of the pesticides than do agricultural uses. Results for diazinon, carbaryl, and chlorpyrifos agree with the results of Larson and others (1999) who report that these three pesticides were detected more often in streams that drain urban basins than in streams that drain agricultural basins throughout the Nation.

The areal variation of prometon concentrations in streamwater throughout the Delaware River Basin also supports the importance of nonagricultural uses as sources to the streams. The greatest concentrations in streamwater samples during May to June occurred in areas with the largest population density (fig. 11). These samples were collected under base-flow conditions during May to June 1999, 2000, or 2001 at sites with a subbasin area less than or equal to $250 \mathrm{mi}^{2}$.

Relations between concentration of simazine and subbasin characteristics do not indicate that either agricultural uses or nonagricultural uses appear to be more important than the other. The high frequency of detection (78.9 percent of samples) indicates that both types of uses may have been important. Agricultural uses of simazine in the Delaware River Basin (table 5) are indicated in the information in Gianessi and Marcelli (2000). Information in Larson and others (1999), however, indicates that, in streams nationwide, nonagricultural uses may be greater than agricultural uses; simazine was detected more often in streams that drain urban basins than in streams that drain agricultural basins.

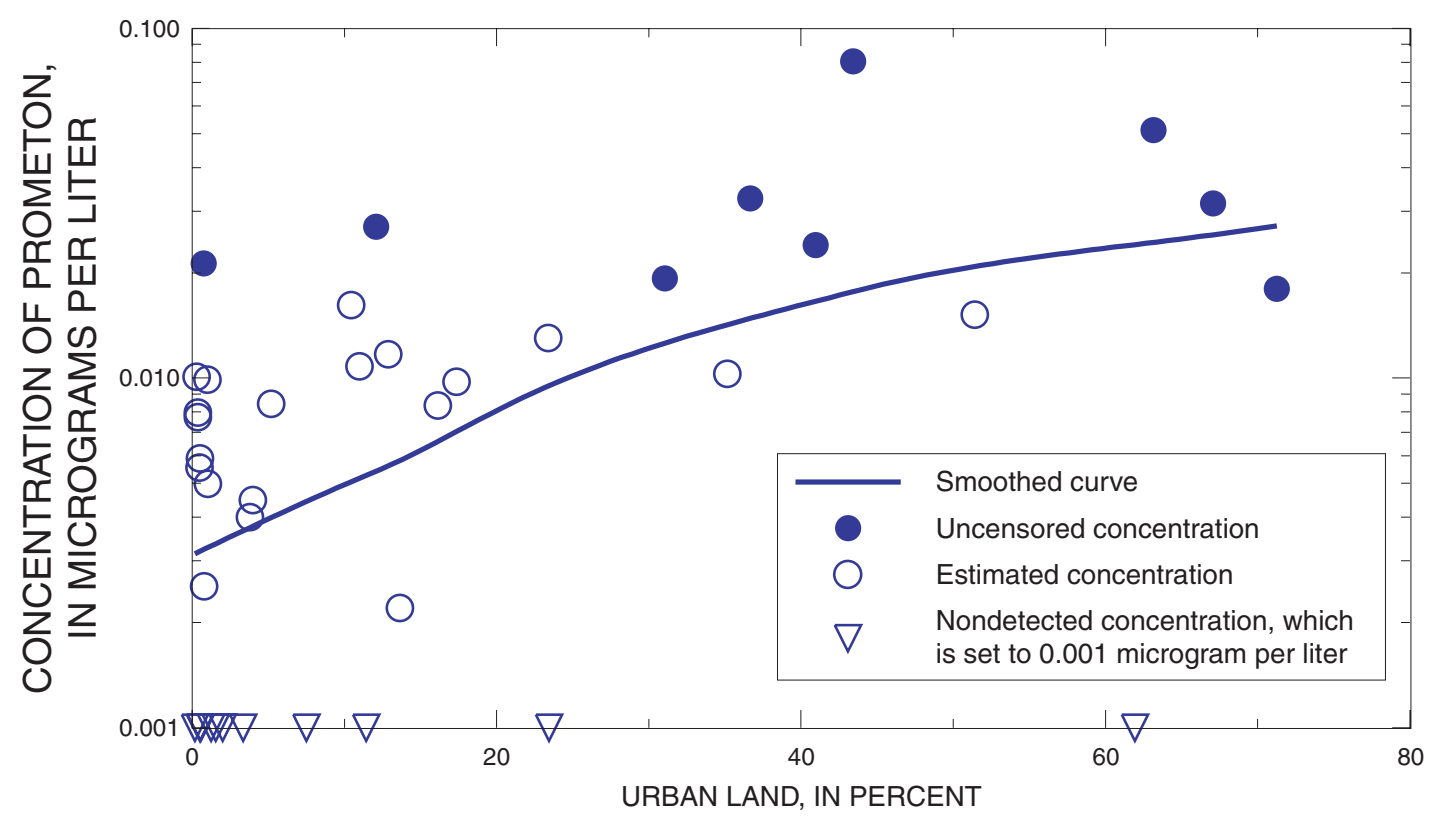

Figure 10. Relation of concentrations of prometon in streamwater to the percentage of urban land in subbasins of the Delaware River Basin, May and June 2000. (Concentrations were measured under base-flow conditions.) 
Table 6. Relations of concentrations of selected pesticides in streamwater to population density, and relations of concentrations of selected pesticides to percentage of urban land in subbasins of the Delaware River Basin, 2000.

[For pesticides in bold type, at least one relation indicated that concentrations increased with an increase in either population density or percentage of urban land in subbasin; Increased, concentrations increased with an increase in population density or percentage of urban land in subbasin; Decreased, concentrations decreased with an increase in population density or percentage of urban land in subbasin; --, concentrations did not increase or decrease; Not tested, relations not evaluated. Samples were collected at sites in the Piedmont and Valley and Ridge Provinces during base-flow conditions. Relations were identified by use of Kendall's tau at a 0.05 level of significance.]

\begin{tabular}{|c|c|c|c|c|c|c|}
\hline \multirow[b]{2}{*}{ Pesticide } & \multirow{2}{*}{$\begin{array}{c}\text { Frequency of } \\
\text { detection, in } \\
\text { percent of all } \\
\text { streamwater } \\
\text { samples }\end{array}$} & \multirow{2}{*}{$\begin{array}{l}\text { Amount applied to } \\
\text { agricultural land in the } \\
\text { Delaware River Basin, } \\
\text { in pounds per year }\end{array}$} & \multicolumn{2}{|c|}{$\begin{array}{c}\text { Concentrations in samples collected during } \\
\text { May-June } 2000 \\
\text { (1 sample at each of } 40 \text { sites) }\end{array}$} & \multicolumn{2}{|c|}{$\begin{array}{c}\text { Concentrations in samples collected during } \\
\text { August-September } 2000 \\
\text { (1 sample at each of } 30 \text { sites) }\end{array}$} \\
\hline & & & $\begin{array}{c}\text { Relations of } \\
\text { concentrations to an } \\
\text { increase in population } \\
\text { density in subbasin in } 2000\end{array}$ & $\begin{array}{c}\text { Relations of } \\
\text { concentrations to an } \\
\text { increase in percentage of } \\
\text { urban land in subbasin }\end{array}$ & $\begin{array}{c}\text { Relations of } \\
\text { concentrations to an } \\
\text { increase in population } \\
\text { density in subbasin in } \mathbf{2 0 0 0}\end{array}$ & $\begin{array}{c}\text { Relations of } \\
\text { concentrations to an } \\
\text { increase in percentage of } \\
\text { urban land in subbasin }\end{array}$ \\
\hline Atrazine & 90.2 & 350,000 & Decreased & Decreased & Decreased & Decreased \\
\hline Metolachlor & 86.1 & 460,000 & Decreased & Decreased & -- & -- \\
\hline Simazine & 78.9 & 36,000 & -- & -- & -- & -- \\
\hline Prometon & 58.8 & 0 & Increased & Increased & Increased & Increased \\
\hline Diazinon & 34.6 & 3,000 & Increased & Increased & Increased & Increased \\
\hline Carbaryl & 33.0 & 13,000 & Increased & Increased & -- & -- \\
\hline Tebuthiuron & 20.3 & 0 & -- & Increased & Increased & Increased \\
\hline Trifluralin & 12.0 & 3,000 & Increased & Increased & -- & -- \\
\hline Chlorpyrifos & 11.1 & 46,000 & -- & -- & Increased & Increased \\
\hline Alachlor & 11.1 & 85,000 & -- & -- & -- & -- \\
\hline Pendimethalin & 10.9 & 170,000 & -- & -- & -- & -- \\
\hline Acetochlor & 9.8 & 59,000 & -- & -- & -- & -- \\
\hline Cyanazine & 9.6 & 47,000 & -- & -- & -- & -- \\
\hline
\end{tabular}




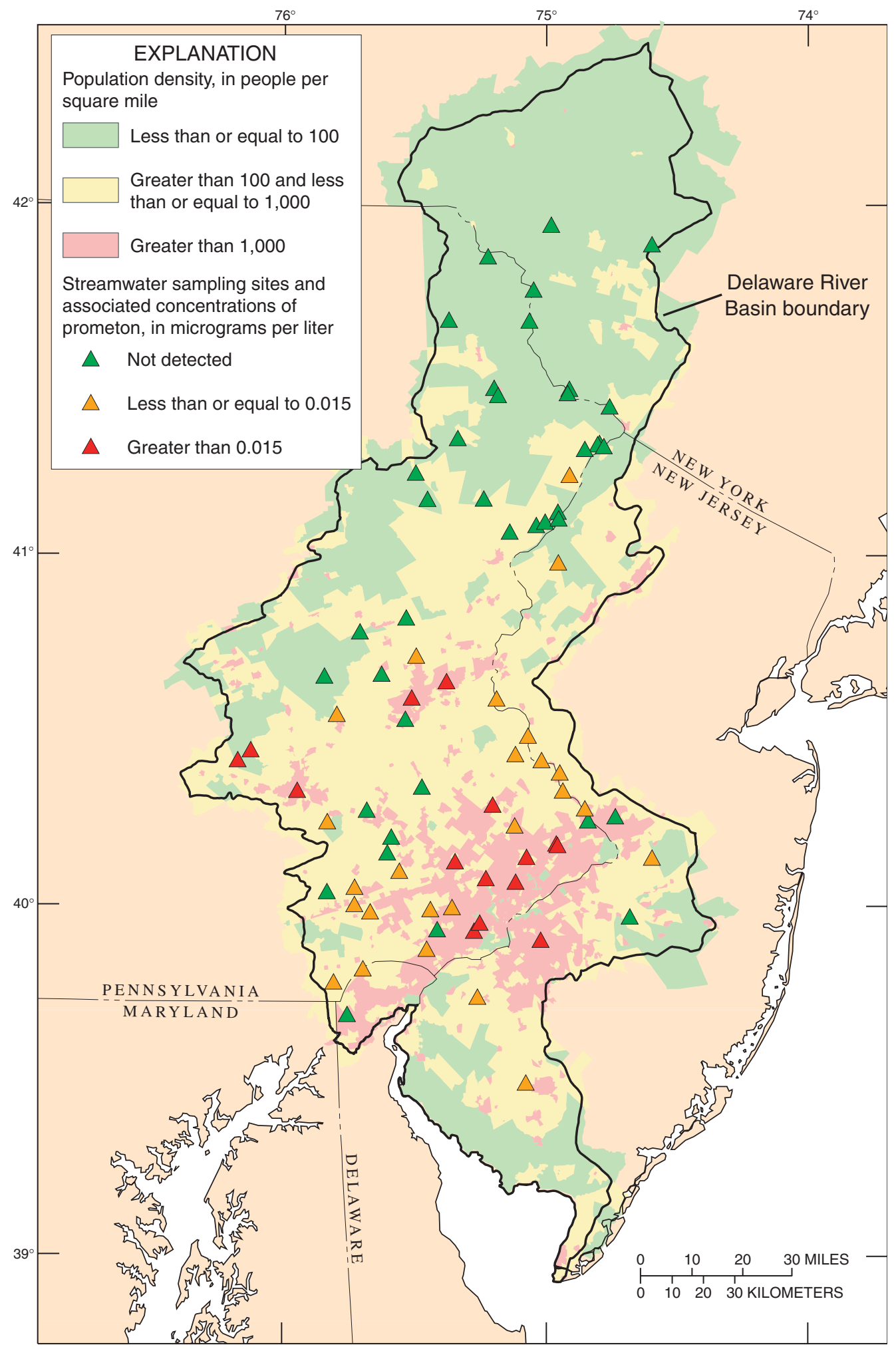

Figure 11. Streamwater sampling sites and associated concentrations of prometon under baseflow conditions, and population density, Delaware River Basin, May and June 1999-2001. 


\section{Pesticide Compounds in Streamwater in the Delaware River Basin, December 1998-August 2001}

Relations between concentrations of alachlor, acetochlor, or cyanazine and subbasin characteristics do not indicate that either agricultural uses or nonagricultural uses appear to be more important than the other. Information in Larson and others (1999) indicates that, in streams nationwide, agricultural uses of alachlor and cyanazine were more important than nonagricultural uses; alachlor and cyanazine were among the pesticides most often detected in streams that drain agricultural basins. Acetochlor, which was not included in the analysis by Larson and others (1999), commonly is applied to corn (U.S. Environmental Protection Agency, 2003a).

A reduction in the amount of use during the period of study could explain why the importance of agricultural uses was not indicated for cyanazine by relations between concentration and basin characteristics. Sales of cyanazine were cancelled at the end of 1999 (U.S. Environmental Protection Agency, undated).

Results of this analysis indicate that pesticides used on agricultural land appear to be different from those used on urban land. One implication of these results is that, in agriculturalland-use areas being converted to urban land use, the types of pesticides detected in the streams likely will change.

\section{Variation in Concentrations of Selected Pesticides with Season}

In general, pesticide concentrations during the growing season (April-October) were greater than those during the nongrowing season (November-March). This result was expected because pesticides generally are applied more often during the growing season. The differences in pesticide concentrations by season are shown in time-series plots (figs. 12 and 13) of concentrations of selected pesticides at the 10 fixed sites.

For atrazine, metolachlor, and acetochlor, the greatest concentrations generally occurred during May, June, and July; concentrations of atrazine and acetochlor are shown in figure 12 as examples. This pattern is the same as that reported by Larson and others (1999) for concentrations of pesticides in streamwater leaving agricultural basins nationwide. Larson and others noted that this pattern usually has been attributed to pesticides applied in the spring and carried to streams by rainwater runoff soon after application. As previously discussed, atrazine and metolachlor in streamwater appear to be attributable more to agricultural uses than to nonagricultural uses. Although the same evaluation did not indicate that acetochlor in streamwater came from agricultural uses, the only known use found for acetochlor is on corn, which indicates that this pesticide was used predominantly for agricultural purposes.

None of the pesticides that appear to be attributable more to nonagricultural uses than agricultural uses showed this pattern of greatest concentrations during May to July that is shown by atrazine, metolachlor, and acetochlor. This result could be attributable to the application of these pesticides (prometon, diazinon, carbaryl, tebuthiuron, trifluralin, and chlorpyrifos) throughout the growing season rather than just during the beginning.

\section{Relations of Concentrations of Selected Pesticides to Streamwater Turbidity}

Relations between concentrations of selected pesticides and streamwater turbidity were identified to determine whether concentrations in streams during stormflow conditions were greater than concentrations in streamwater during base-flow conditions. For this report, streamwater turbidity was used as an indicator of stormflow and base-flow conditions. The turbidity of the streamwater during stormflow conditions usually is greater than the turbidity during base flow because, during stormflow conditions, streamwater usually contains particulate material washed off the land surface and(or) resuspended from the streambed, and particulate material usually is not present during base-flow conditions.

Relations of concentration to turbidity were identified by use of Kendall's tau and data collected during the growing season at the 10 fixed sites. Only concentrations during the growing season were included because those concentrations tended to be greater than the concentrations during the non-growing season, and relations between concentrations and turbidity were more likely to be identified. An example of one relation is shown in figure 14.

Relations between concentrations of pesticides and streamwater turbidity are summarized by pesticide in table 7 . For each pesticide, the number of sites at which concentrations increased with increases in turbidity is shown. No relation was determined for decreases in concentrations with increases in turbidity.

Metolachlor and diazinon were more likely than the other pesticides to be present in greater concentrations during stormflow than during base flow. Of the 10 fixed sites sampled, concentrations of metolachlor and diazinon increased with increases in turbidity at 8 and 6 sites, respectively (table 7). For the other pesticides tested, such relations were determined for no more than four sites.

These results indicate that, in general, large amounts of metolachlor and diazinon (in the dissolved form) were washed off the land surface during storms. One implication of these results is that any interpretation of concentrations of metolachlor and diazinon should consider whether the concentrations were measured during stormflow or base flow. 
(A) Atrazine

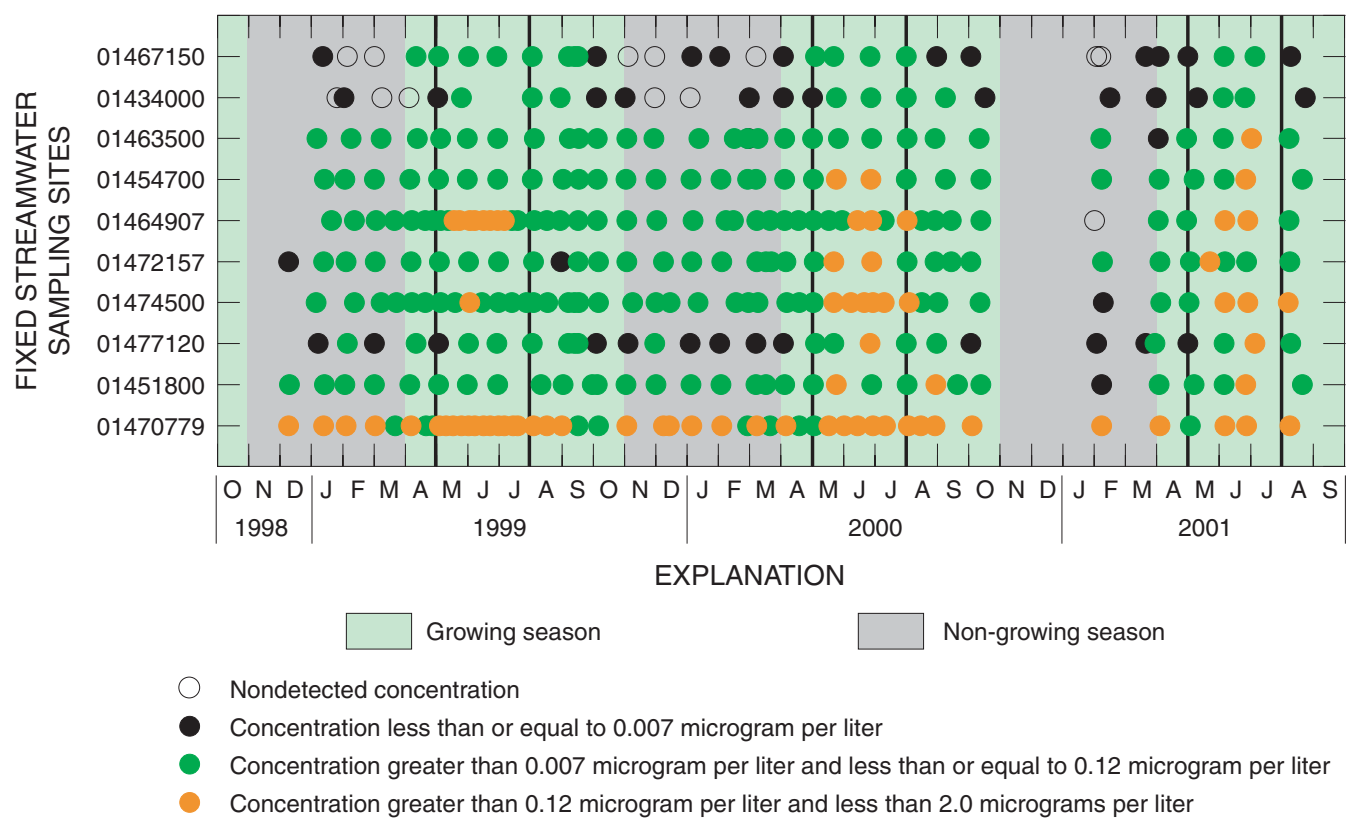

(B) Acetochlor

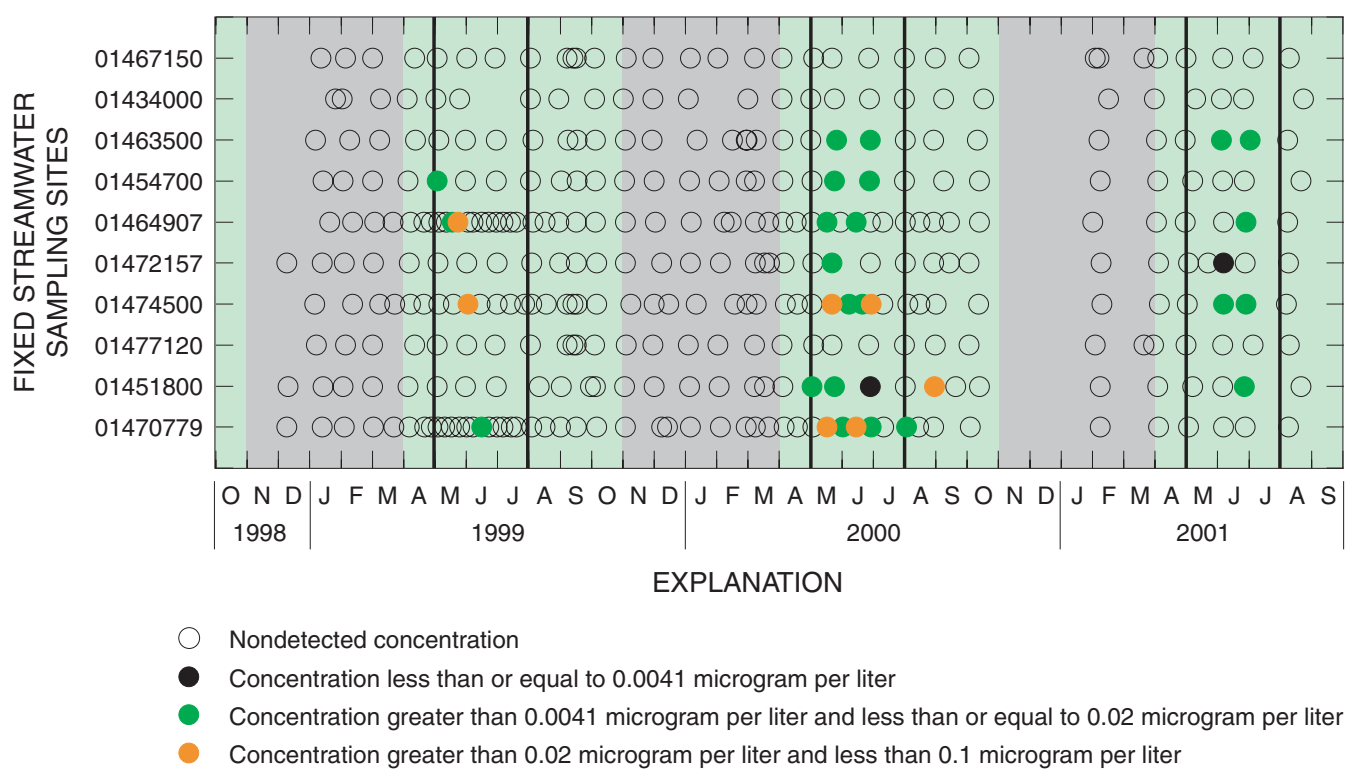

Figure 12. Concentrations of $(A)$ atrazine, and $(B)$ acetochlor in streamwater samples from fixed sites in the Delaware River Basin, December 1998-August 2001. (Sites, indicated by station number, are listed in order, from bottom to top, of decreasing percentage of basin composed of agricultural land. Names of sites are listed in table 1. Vertical lines are at May 1 and July 31.$)$ 


\section{(A) Prometon}

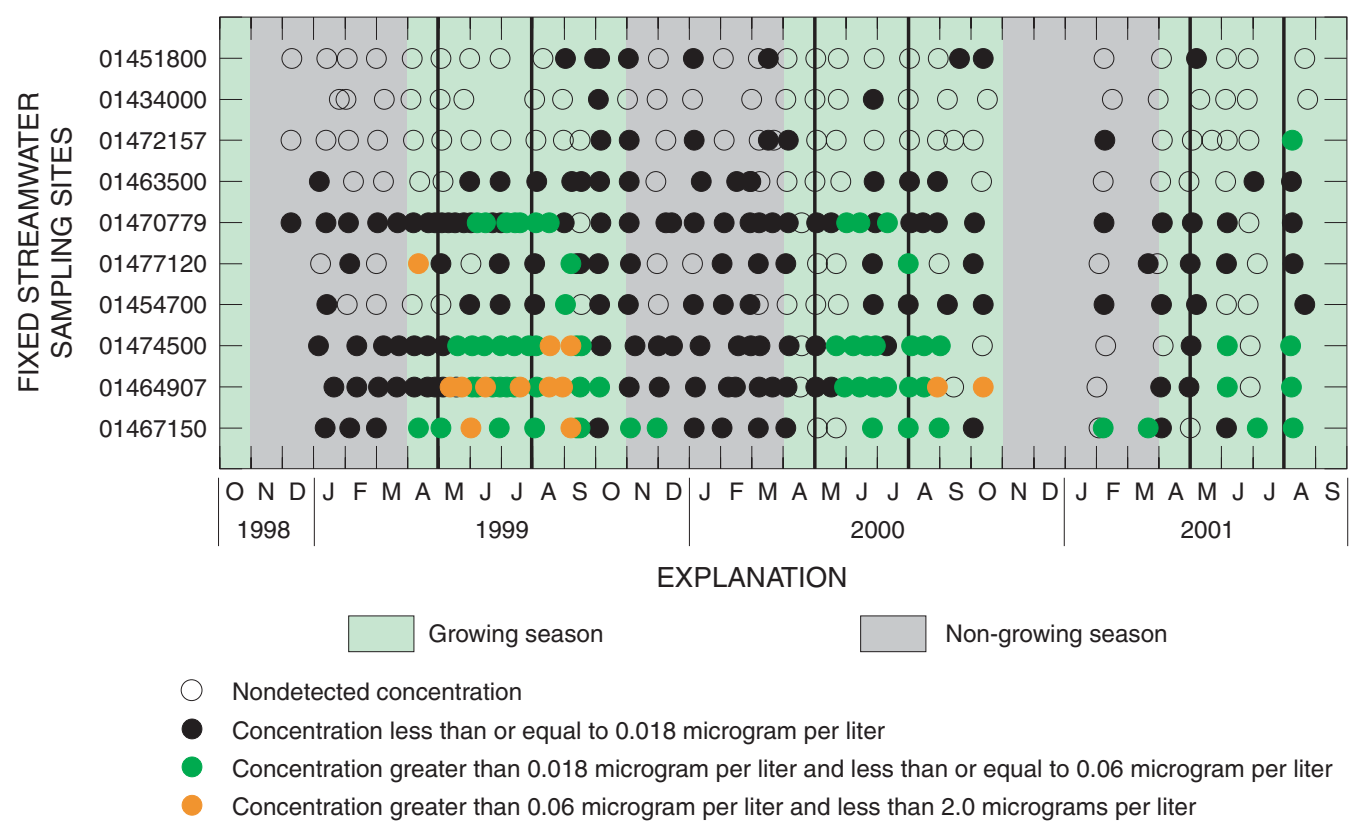

(B) Diazinon

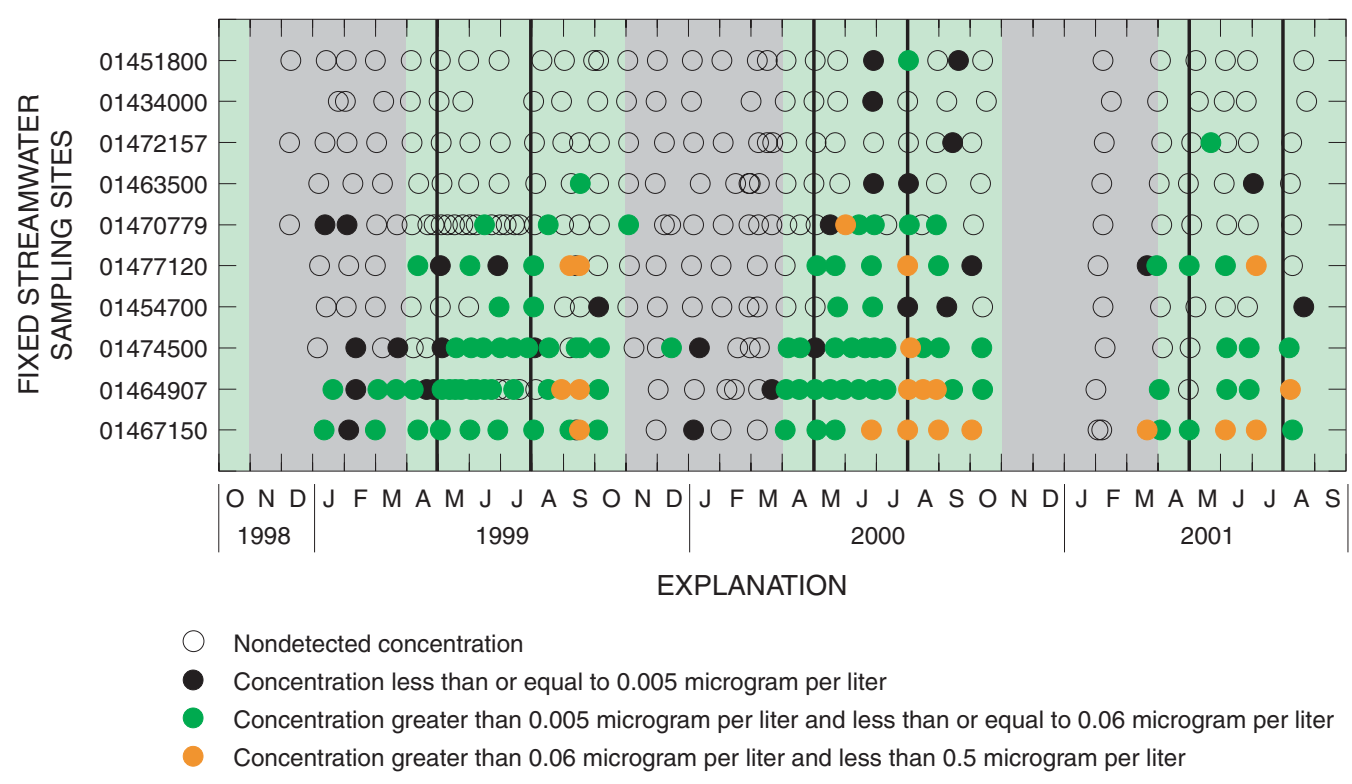

Figure 13. Concentrations of $(A)$ prometon, and $(B)$ diazinon in streamwater samples from fixed sites in the Delaware River Basin, December 1998-August 2001. (Sites, indicated by station number, are listed in order, from bottom to top, of decreasing percentage of basin composed of urban land. Names of sites are listed in table 1. Vertical lines are at May 1 and July 31.) 


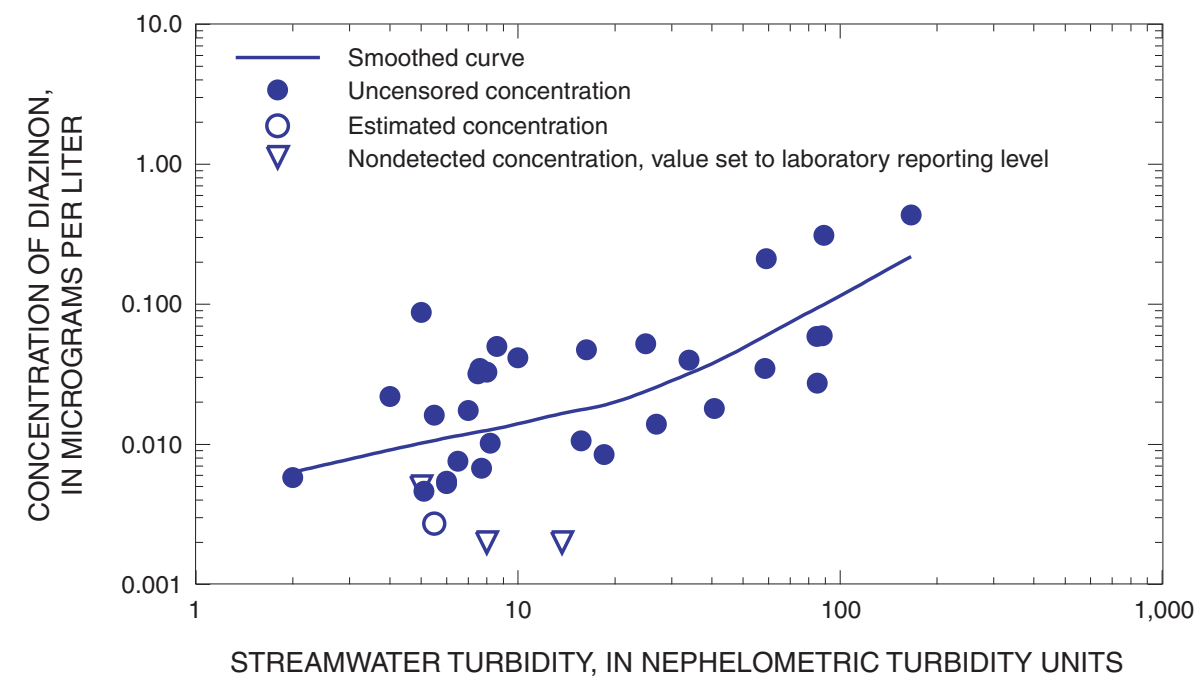

Figure 14. Relation of diazinon concentration to streamwater turbidity at streamwater sampling site 01464907, Little Neshaminy Creek near Neshaminy, Pa., April-October, 1999-2001.

Table 7. Summary of relations of concentrations of selected pesticides to streamwater turbidity at fixed streamwater sampling sites in the Delaware River Basin, April-0ctober, 1999-2001.

[For pesticides in bold type, concentrations increased with increases in streamwater turbidity at six or more sites; these pesticides were detected in 8 percent or more of all samples. For each fixed site, the number of samples included in the analysis ranged from 13 to 33 . Relations were identified by use of Kendall's tau and have a 0.05 level of significance. No relation showed decreasing concentration with increasing streamwater turbidity.]

\begin{tabular}{lcc}
\hline Pesticide & $\begin{array}{c}\text { Frequency of } \\
\text { detection, in } \\
\text { percent of all } \\
\text { samples }\end{array}$ & $\begin{array}{c}\text { Number of fixed sites with } \\
\text { relations showing increasing } \\
\text { concentration with increases } \\
\text { in streamwater turbidity }\end{array}$ \\
\hline Atrazine & 90.2 & 3 \\
Metolachlor & 86.1 & 8 \\
Simazine & 78.9 & 1 \\
Prometon & 58.8 & 1 \\
Diazinon & 34.6 & 6 \\
Carbaryl & 33.0 & 2 \\
Tebuthiuron & 20.3 & 1 \\
Trifluralin & 12.1 & 2 \\
Chlorpyrifos & 11.1 & 4 \\
Alachlor & 11.1 & 2 \\
& & 4 \\
Pendimethalin & 10.9 & 2 \\
Acetochlor & 9.8 & 3 \\
Cyanazine & 9.6 & \\
\hline
\end{tabular}

\section{Comparison of Concentrations of Selected Degradation Products with Concentrations of Parent Pesticides}

\section{Deethylatrazine}

Deethylatrazine, which was detected in 82.5 percent of samples, was most frequently detected GC pesticide degradation product and the third most frequently detected GC pesticide compound (table 3, fig. 6). Deethylatrazine has been detected commonly in streams nationwide, and is the fifth most often detected pesticide compound in 50 streams (Larson and others, 1999). The high frequency of detection of deethylatrazine is likely related to the presence of atrazine, its parent pesticide, in streamwater; atrazine was the pesticide most often detected in this study and in the study by Larson and others (1999).

The concentration of deethylatrazine generally increased with the concentration of atrazine in the samples (fig. 15). This correlation appears to indicate that the greater the amount of atrazine in the streamwater, the greater the amount of atrazine that has degraded to deethylatrazine. Only samples with detected concentrations of deethylatrazine or atrazine were included in this analysis.

The relation between concentrations of deethylatrazine and atrazine is dependent upon the time of the year in which the sample was collected (fig. 15). For a given atrazine concentration, the corresponding concentration of deethylatrazine in samples collected during May to July was less than the deethylatrazine concentration in samples collected during August to April. 


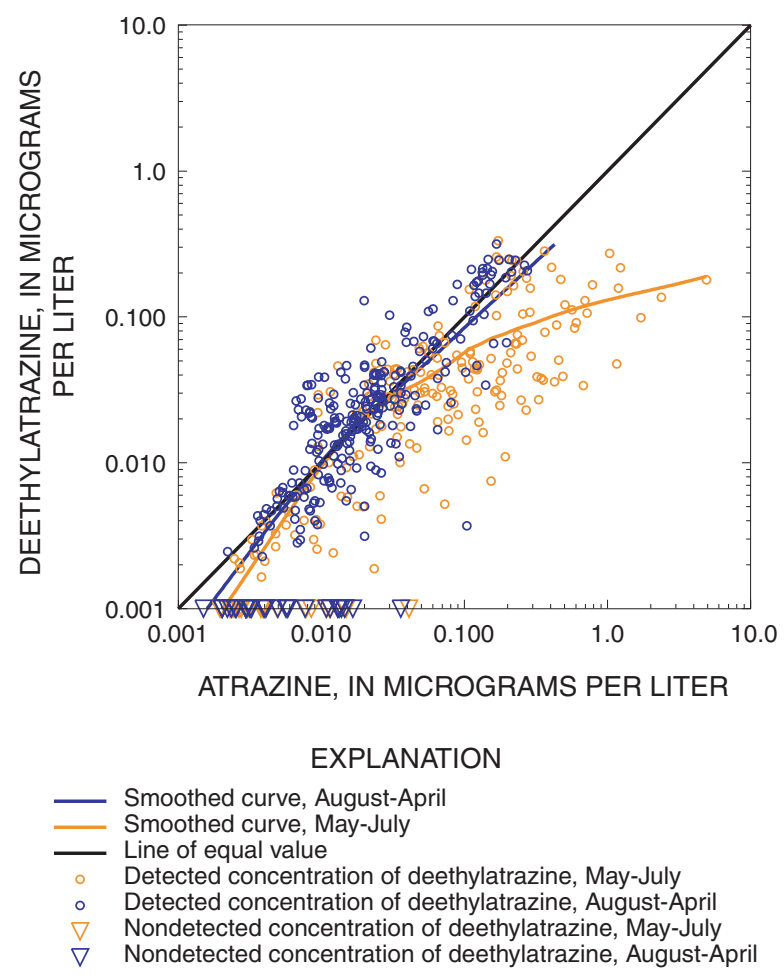

Figure 15. Relation of concentrations of deethylatrazine to concentrations of atrazine in streamwater samples from the Delaware River Basin, 1998-2001. (Only samples with detected concentrations of deethylatrazine or atrazine were included. All nondetected concentrations were set to 0.001 microgram per liter.)

This difference may be attributable to the time of application of atrazine to agricultural land. The atrazine concentrations in streamwater during May to July were greater than during other months (fig. 12), suggesting application just prior to or during this period. If so, atrazine in streamwater during May to July did not have as much time to decay to deethylatrazine as did atrazine in streamwater during the remaining months of the year.

\section{Ethane Sulfonic Acid and Oxanilic Acid Degradation Products of Alachlor, Acetochlor, and Metolachlor at Two Sites}

The frequencies of detection of the ESA and OA degradation products as a function of the frequencies of detection of the parent pesticides are shown in figure 16. A common reporting level of $0.05 \mu \mathrm{g} / \mathrm{L}$ was used to compare the frequencies of detection because the laboratory reporting level for the degradation products $(0.05 \mu \mathrm{g} / \mathrm{L})$ was greater than the laboratory reporting levels for the parent pesticides (table 3). Samples were consid-

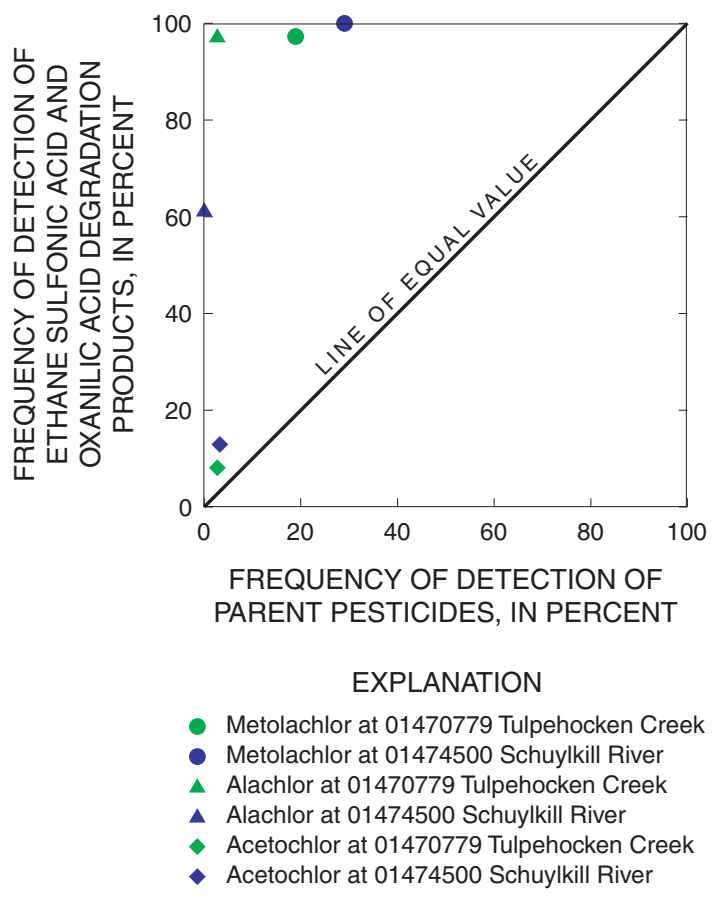

Figure 16. Relation of frequency of detection of ethane sulfonic acid and oxanilic acid degradation products to the frequency of detection of metolachlor, alachlor, and acetochlor in 68 streamwater samples from two sites in the Delaware River Basin, 1999-2000. (Only concentrations greater than or equal to 0.05 microgram per liter are considered to be detected.)

ered to contain detected degradation products if the concentration of either the ESA or OA degradation product equaled or exceeded $0.05 \mu \mathrm{g} / \mathrm{L}$ in the 68 samples analyzed for both degradation products and parent pesticides.

The ESA or OA degradation products of alachlor, acetochlor, and metolachlor were detected at concentrations greater than or equal to $0.05 \mu \mathrm{g} / \mathrm{L}$ more often than were the parent pesticides (fig. 16). The degradation products of alachlor and metolachlor were detected in at least 60 percent of samples, and the parent pesticides were detected in less than 30 percent.

The concentrations of either the ESA or OA degradation product usually exceeded the concentrations of the parent pesticide (for example, see figure 17). In addition, concentrations of the ESA degradation products of metolachlor and alachlor usually exceeded the concentrations of the respective OA degradation product (for example, see figure 17). Similar results have been shown by studies of pesticide degradation products in streams in Iowa (Kalkhoff and other, 1998); Illinois, Iowa, and Minnesota (Kalkhoff and others, 2003); and New York (Phillips and others, 1999). 


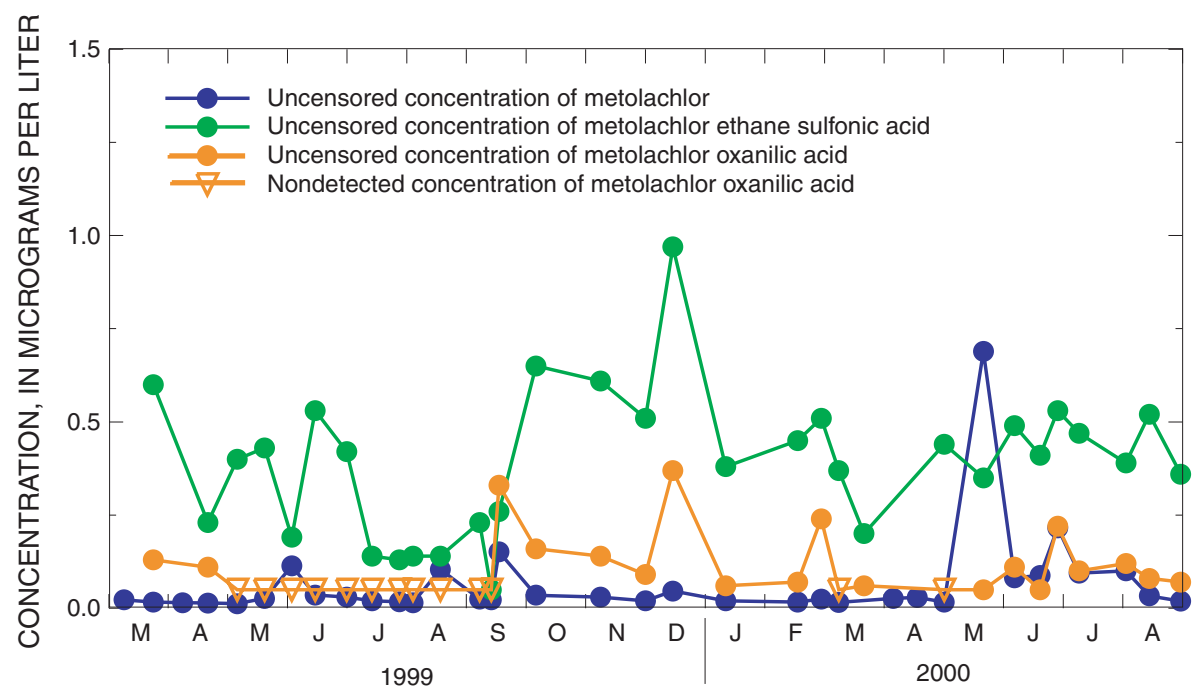

Figure 17. Concentrations of metolachlor and its degradation products at fixed site 01474500 , Schuylkill River at Philadelphia, Pa., March 1999-August 2000.

\section{Comparison of Concentrations of Pesticide Compounds to Standards and Guidelines for the Protection of Human Health and Aquatic Life}

In this section, some of the deleterious effects of pesticide compounds in water on human health and aquatic life are assessed. Some effects not addressed in this analysis are mentioned.

Standards and guidelines included in this analysis are values accepted by the U.S. Environmental Protection Agency (USEPA), the Canadian Council of Ministers of the Environment (CCME), or the International Joint Commission United States and Canada (IJC) (table 8). Standards are enforced legally, and guidelines are advisory.

\section{Human Health}

Potential effects of pesticide compounds on human health through consumption of streamwater were assessed by comparing concentrations of pesticide compounds to drinking-water standards and guidelines accepted by the USEPA (table 8). For each pesticide compound, the value of the maximum contaminant level (MCL), if available, was used. An MCL, the maximum permissible level of a contaminant in water that is delivered to any user of a public water system, is a legally enforced standard. An MCL is set as close to the maximum contaminant level goal as feasible, using the best available analytical and treatment technologies and taking cost into consideration; the maximum contaminant level goal is the level at which no known or anticipated adverse effect to health occurs and which allows an adequate margin of safety.

If there was no value for the MCL for a specified compound, the smaller of either of the following two guidelines was used: the lifetime health advisory (HAL) or the risk-specific dose at $10^{-5}$ cancer risk (RSD5). The HAL is the concentration of a chemical in drinking water that is not expected to cause any adverse noncarcinogenic effects for a lifetime of exposure. The RSD5 is the concentration of a chemical in drinking water that corresponds to an excess estimated lifetime cancer risk of 1 in 100,000 .

Of the 35 pesticide compounds detected, drinking-water standards or guidelines are available for 21 (table 8). A summary of concentrations and standards or guidelines is provided in table 3.

Out of 531 samples analyzed for GC pesticide compounds, only 7 samples contained concentrations of at least one compound that exceeded its drinking-water standard or guideline (table 3 ). These samples were collected under base-flow conditions at synoptic sites during spring and late summer 2000.

Atrazine, simazine, and dieldrin were the only pesticide compounds for which at least one concentration exceeded the drinking-water standard or guideline (table 3). Dieldrin exceeded the guideline in five samples from the following sites: 0146708450, Tacony Creek at Cheltenham, Pa.; 01475510, Darby Creek near Darby, Pa.; and 01475543, Cobbs Creek at East Lansdowne, Pa. Atrazine exceeded the standard in one sample from 01478200, Middle Branch White Clay Creek near Landenberg, $\mathrm{Pa}$., and simazine exceeded the standard in one sample from site 01472100, Pigeon Creek near Parker Ford, Pa. 
Table 8. Selected standards and guidelines for the protection of the health of humans and aquatic life from pesticide compounds in streamwater.

[ $\mu \mathrm{g} / \mathrm{L}$, micrograms per liter; --, not available or applicable; MCL, maximum contaminant level; USEPA, U.S. Environmental Protection Agency; HAL, lifetime health advisory; RSD5, risk specific dose at $10^{-5}$ cancer risk; CAN, Canadian water-quality guideline for the protection of freshwater aquatic life; CANinterim, interim value for Canadian water-quality guideline for the protection of freshwater aquatic life; USEPA CCC, chronic water-quality criterion for protection of freshwater aquatic organisms; GRL, Great Lakes water-quality objective for protection of aquatic life; IJC, International Joint Commission United States and Canada; CCME, Canadian Council of Ministers of the Environment; HPLC, high performance liquid chromatography; GC, gas chromatography; ESA, ethane sulfonic acid; OA, oxanilic acid]

\begin{tabular}{|c|c|c|c|c|c|c|}
\hline \multirow{3}{*}{$\begin{array}{l}\text { Pesticide } \\
\text { compound }\end{array}$} & \multicolumn{6}{|c|}{ Selected standards and guidelines } \\
\hline & \multicolumn{3}{|c|}{ Drinking water } & \multicolumn{3}{|c|}{ Aquatic life } \\
\hline & $\begin{array}{l}\text { Value, } \\
\text { in } \mu \mathrm{g} / \mathrm{L}\end{array}$ & Type & Reference & $\begin{array}{l}\text { Value, } \\
\text { in } \mu \mathrm{g} / \mathrm{L}\end{array}$ & Type & Reference \\
\hline \multicolumn{7}{|c|}{ GC pesticide compounds } \\
\hline Acetochlor & -- & -- & -- & -- & -- & -- \\
\hline Alachlor & 2 & MCL & USEPA (2002b) & -- & -- & -- \\
\hline Atrazine & 3 & MCL & USEPA (2002b) & 1.8 & CAN & $\operatorname{CCME}(2002 a, b)$ \\
\hline Azinphos, methyl & -- & -- & -- & .01 & USEPA CCC & USEPA (2002c) \\
\hline Benfluralin & -- & -- & -- & -- & -- & -- \\
\hline Carbaryl & 700 & HAL & USEPA (2002b) & .2 & CAN & $\operatorname{CCME}(2002 a, b)$ \\
\hline Carbofuran & 40 & MCL & USEPA (2002b) & 1.8 & $\mathrm{CAN}$ & CCME $(2002 a, b)$ \\
\hline Chlorpyrifos & 20 & HAL & USEPA (2002b) & .041 & USEPA CCC & USEPA (2002c) \\
\hline Cyanazine & 1 & HAL & USEPA (2002b) & 2 & CAN - interim & $\operatorname{CCME}(2002 a, b)$ \\
\hline Dacthal & 70 & HAL & USEPA (2002b) & -- & -- & -- \\
\hline p,p'-DDE & 1 & RSD5 & USEPA (2003c) & 1.001 & USEPA CCC & USEPA (2002c) \\
\hline Deethylatrazine & -- & -- & -- & -- & -- & -- \\
\hline Diazinon & 6 & HAL & USEPA (2002b) & .08 & GRL & IJC (1978) \\
\hline Dieldrin & .02 & RSD5 & USEPA (2002b) & .056 & USEPA CCC & USEPA (2002c) \\
\hline EPTC & -- & -- & -- & -- & -- & - \\
\hline Lindane & .2 & MCL & USEPA (2002b) & .01 & CAN & $\operatorname{CCME}(2002 a, b)$ \\
\hline Linuron & -- & -- & -- & 7 & CAN & $\operatorname{CCME}(2002 a, b)$ \\
\hline Malathion & 100 & HAL & USEPA (2002b) & .1 & USEPA CCC & USEPA (2002c) \\
\hline Metolachlor & 100 & HAL & USEPA (2002b) & 7.8 & CAN-interim & $\operatorname{CCME}(2002 a, b)$ \\
\hline Metribuzin & 200 & HAL & USEPA (2002b) & 1 & CAN-interim & $\operatorname{CCME}(2002 a, b)$ \\
\hline Napropamide & -- & -- & -- & -- & -- & -- \\
\hline Pendimethalin & -- & -- & -- & -- & -- & -- \\
\hline Prometon & 100 & HAL & USEPA (2002b) & -- & -- & -- \\
\hline Pronamide & 50 & HAL & USEPA (2002b) & -- & -- & -- \\
\hline Propachlor & 90 & HAL & USEPA (2002b) & -- & -- & -- \\
\hline Propanil & -- & -- & -- & -- & -- & -- \\
\hline Simazine & 4 & MCL & USEPA (2002b) & 10 & CAN & $\operatorname{CCME}(2002 a, b)$ \\
\hline Tebuthiuron & 500 & HAL & USEPA (2002b) & 1.6 & CAN-interim & $\operatorname{CCME}(2002 a, b)$ \\
\hline Terbacil & 90 & HAL & USEPA (2002b) & -- & -- & -- \\
\hline Trifluralin & 5 & HAL & USEPA (2002b) & .2 & $\mathrm{CAN}$ & $\operatorname{CCME}(2002 a, b)$ \\
\hline \multicolumn{7}{|c|}{ HPLC pesticide degradation products } \\
\hline Acetochlor ESA & -- & -- & -- & -- & -- & -- \\
\hline Acetochlor OA & -- & -- & -- & -- & -- & -- \\
\hline Alachlor ESA & -- & -- & -- & -- & -- & -- \\
\hline Metolachlor ESA & -- & -- & -- & -- & -- & -- \\
\hline Metolachlor OA & -- & -- & -- & -- & -- & -- \\
\hline
\end{tabular}

${ }^{1}$ Total DDT. 
Concentrations of atrazine, dieldrin, and simazine in other streams outside of the Delaware River Basin have exceeded drinking-water standards or guidelines. Out of 50 streams throughout the Nation, atrazine, dieldrin, and simazine exceeded standards or guidelines in samples from 16, 4, and 6 streams, respectively (Larson and others, 1999).

The comparison described here shows there is little hazard to humans through the consumption of streamwater with reported pesticide concentrations. The apparent hazard probably is less than that presented in this analysis because processes used to treat streamwater for drinking probably reduce the concentrations of pesticide compounds in drinking water.

Other effects were not addressed by this analysis. These include (1) the effects of the 14 pesticide compounds without drinking-water standards or guidelines (tables 3 and 8), (2) the combined effects of more than one compound, and (3) the effects of compounds on the human endocrine system. The human endocrine system is a set of glands that produce hormones which help guide development, growth, reproduction, and behavior. A description of endocrine systems in animals, including humans, is given in Encyclopedia Britannica, Inc. (1997).

\section{Aquatic Life}

Effects of pesticide compounds on aquatic plants and animals living in the streams were assessed by comparing concentrations to guidelines for streamwater concentrations designed to protect aquatic life. Three types of guidelines to protect the plants and animals in streams were used in this analysis (table 8). If available, the chronic water-quality criterion (CCC) was used (U.S. Environmental Protection Agency, 2002b). The $\mathrm{CCC}$ is an estimate of the highest concentration of material in surface water to which an aquatic community can be exposed indefinitely without resulting in an unacceptable effect.

If no CCC was available, the Canadian water-quality guideline for the protection of freshwater aquatic life (CAN) was used (Canadian Council of Ministers of the Environment, 2002a, 2002b) (table 8). Values of CAN, intended to protect all forms of aquatic life during all stages of the aquatic life cycle, are not to be exceeded at any time. Some values of CAN are interim and have had less rigorous data requirements than final values.

For diazinon, the value of the Great Lakes water-quality objective (International Joint Commission United States and Canada, 1978) was used in this analysis (table 8). This value represents the minimum level of water quality desired in the boundary waters of the Great Lakes System. Values for the chronic water-quality criteria or the Canadian water-quality guideline were not available for diazinon.

A summary of pesticide concentrations and aquatic-life guidelines is presented in table 3. Guidelines were not available for 18 of the 35 detected pesticides and degradation products.

Of the 531 samples analyzed for GC pesticide compounds, 29 samples contained concentrations of one or more compounds that clearly exceeded the aquatic-life guidelines (table 3). A least one concentration of the following pesticide compounds exceeded guidelines: diazinon (19 samples), carbaryl (7 samples), lindane (2 samples), atrazine (2 samples), and chlorpyrifos (1 sample).

Concentrations of atrazine, chlorpyrifos, diazinon, and lindane reported in other streams throughout the Nation have exceeded aquatic-life guidelines (Larson and others, 1999). Guidelines for carbaryl were not part of the analysis by Larson and others.

Diazinon appears to be the pesticide most likely to have adversely affected aquatic life in the streams of the Delaware River Basin; diazinon exceeded the guideline in more samples (19) than did the other pesticide compounds (table 3). Of these 19 samples, 15 were collected at the following three fixed sites: 01464907, Neshaminy Creek at Valley Road near Neshaminy, Pa.; 01467150, Cooper River at Haddenfield, N.J.; and 01477120, Raccoon Creek near Swedesboro, N.J.

Concentrations of p,p'-DDE and methyl azinphos also may have exceeded their guidelines in 30 and 6 samples, respectively, but the results of this analysis are less clear than for the other 5 pesticides discussed above. For p,p'-DDE and methyl azinphos, all concentrations and the guidelines were less than the maximum laboratory reporting level (table 3). As a result, there is greater uncertainty in the results for these two pesticides than in the results for the other pesticides that have guidelines and concentrations in streamwater greater than the laboratory reporting level.

The following effects on aquatic life were not addressed by this analysis: (1) the effects of the 18 pesticide compounds for which there are no guidelines, (2) the additive (or synergistic) effects of more than one pesticide compound, (3) the seasonal variation in concentration, and (4) some types of effects, such as endocrine disruption. A recent study (Hayes and others, 2002) reports that endocrine disruption in frogs occurred when they were exposed to water containing atrazine at concentrations less than the Canadian water-quality guideline of $1.8 \mu \mathrm{g} / \mathrm{L}$.

\section{Summary and Conclusions}

During December 1998 to August 2001, 533 samples of streamwater were collected in the Delaware River Basin as part of the USGS National Water-Quality Assessment Program. Most samples were collected monthly at 10 fixed sites; additional samples were collected under base-flow conditions at 84 sites during spring and late summer 1999, 2000, or 2001. Of these samples, 531 samples were analyzed for dissolved concentrations of 47 pesticide compounds ( 43 pesticides and 4 pesticide degradation products); 70 selected samples at two sites were analyzed for six additional pesticide degradation products.

The most often detected compounds were atrazine (90.2 percent of samples), metolachlor (86.1 percent), deethylatrazine ( 82.5 percent), and simazine (78.9 percent). Atrazine, metolachlor, and simazine are pesticides; deethylatrazine is a degradation product of atrazine. 
Of the 6 pesticide degradation products analyzed for in 70 samples at 2 sites, 5 were detected. The most often detected was metolachlor ESA, a degradation product of metolachlor (98.6 percent of samples).

Quality-assurance / quality-control samples provided information on the bias and variability of concentrations of pesticide compounds. Results of analysis of field blanks indicated that, with the exception of p,p'-DDE, concentrations of all pesticide compounds analyzed for probably were not biased as a result of sample contamination. An evaluation of concentrations of pesticide compounds in replicates and streamwater samples indicated that the variability of pesticide concentrations most often detected is small; the median difference between concentrations in streamwater samples and replicates was 4.5 percent.

The concentrations of atrazine, metolachlor, and pendimethalin appear to be attributable more to agricultural uses of these pesticides than to nonagricultural uses. Concentrations of these pesticides in selected samples from sites in the Piedmont and Valley and Ridge Provinces increased with an increase in either the percentage of subbasin composed of agricultural land or the estimated rate of application of these pesticides to agricultural land in the drainage basin. These samples were collected under base-flow conditions during May and June or August and September 2000. These three pesticides are those most heavily applied to agricultural land in the study area; all are applied to corn and (or) soybeans, major crops in the study area.

Concentrations of prometon, diazinon, chlorpyrifos, tebuthiuron, trifluralin, and carbaryl in samples appear to be attributable more to nonagricultural uses of these pesticides than to agricultural uses. Concentrations of these pesticides in selected samples at sites in the Piedmont and Valley and Ridge Provinces increased with an increase in either the fraction of subbasin composed of urban land or the population density in the subbasin. These samples were collected under base-flow conditions either during May and June or August and September 2000 .

The relative importance of either agricultural uses or nonagricultural uses was not indicated by relations between concentrations and basin characteristics for simazine, alachlor, acetochlor, or cyanazine. Of these pesticides, simazine was one of the most often detected (78.9 percent of samples).

In general, pesticide concentrations during the growing season (April-October) were greater than those during the nongrowing season (November-March). This result was expected because pesticides generally are applied more often during the growing season. For atrazine, metolachlor, and acetochlor, the greatest concentrations generally occurred during May, June, and July. This pattern has been attributed to pesticides applied in the spring and carried to streams by rainwater runoff soon after application.

Metolachlor and diazinon were more likely than the other pesticides to show greater concentrations during stormflow than during periods of base flow. This conclusion is based on relations between pesticide concentrations and streamwater turbid- ity; the turbidity of streamwater during stormflow conditions generally is greater than the turbidity of streamwater under base-flow conditions. Concentrations of metolachlor and diazinon increased with increasing turbidity at 8 and 6 sites, respectively, of the 10 fixed sites sampled.

Deethylatrazine was the pesticide degradation product most often detected (82.5 percent of samples) in samples collected at all sites. Concentrations of deethylatrazine increased with an increase in concentrations of atrazine, its parent pesticide.

In samples collected at two sites, concentrations of the ethane sulfonic acid (ESA) or oxanilic acid (OA) degradation products of metolachlor and alachlor usually exceeded concentrations of the parent pesticides. For each of these two pesticides, concentrations of the ESA degradation product usually exceeded concentrations of the OA degradation product.

A comparison of concentrations of pesticide compounds to drinking-water standards or guidelines indicate little hazard to humans through the consumption of streamwater with reported pesticide concentrations; concentrations of atrazine, dieldrin, or simazine exceeded standards or guidelines in only 7 of 531 samples. Not all adverse affects on human health were considered in this analysis, however.

Diazinon appears to be the pesticide compound most likely to have adversely affected aquatic life in the streams of the Delaware River Basin; concentrations of diazinon exceeded the guideline (designed to protect aquatic life) in 19 samples, the most of any pesticide compound. Concentrations of as many as 5 compounds exceeded guidelines in 29 of the 531 samples. Not all adverse effects of pesticides on aquatic life were considered in this analysis.

\section{References Cited}

Canadian Council of Ministers of the Environment, 2002a, Canadian water quality guidelines for the protection of aquatic life: Summary table. Updated, in Canadian environmental quality guidelines, 1999: Canadian Council of Ministers of the Environment, accessed August 5, 2003, at URL http://www.ccme.ca/assets/pdf/e5_002.pdf

Canadian Council of Ministers of the Environment, 2002b, Canadian Environmental Quality Guidelines, Summary Table, 2002: Canadian Council of Ministers of the Environment, accessed August 1, 2003, at URL http://www.ccme.ca/ assets/pdf/e1_06.pdf

Capel, P.D., Spexet, A.H., and Larson, S.J., 1999, Occurrence and behavior of the herbicide prometon in the hydrologic system: Environmental Science and Technology, v. 33, no. 5, p. 674-680.

DeLuca, M.J., Hoppe, H.L., Doyle, H.A., and Gray, B.J, 2002, Water resources data for New Jersey-water year 2001, volume 3. Water-quality data: U.S. Geological Survey Water-Data Report NJ-01-3, 580 p. 
DeLuca, M.J., Mattes, G.L., and Burns, H.L., 2001, Water resources data for New Jersey-water year 2000, volume 3. Water-quality data: U.S. Geological Survey Water-Data Report NJ-00-3, 618 p.

DeLuca, M.J., Romanok, K.M., Riskin, M.L., Mattis, G.L., Thomas, A.M., and Gray, B.J., 2000, Water resources data for New Jersey-water year 1999, volume 3. Water-quality data: U.S. Geological Survey Water-Data Report NJ-99-3, $517 \mathrm{p}$.

Ebbert, J.C., and Embrey, S.S., 2002, Pesticides in surface water of the Yakima River Basin, Washington, 1999-2000, their occurrence and an assessment of factors affecting concentrations and loads: U.S. Geological Survey WaterResources Investigations Report 01-4211, 49 p.

Encyclopedia Britannica, Inc., 1997, Endocrine systems in The New Encyclopedia Britannica: Chicago, Encyclopedia Britannica, Inc., v. 18, p. 287-331.

Fischer, J.M., 1999, National Water-Quality Assessment Program, Delaware River Basin: U.S. Geological Survey Fact Sheet FS-056-99, 6 p.

Fuhrer, G. J., and others, 1999, The quality of our Nation's waters, nutrients and pesticides: U.S. Geological Survey Circular 1225, $82 \mathrm{p}$.

Gianessi, L.P, and Marcelli, M.B., 2000, Pesticide use in U.S. crop production, 1997, national summary report, November 2000: Washington, D.C., National Center for Food and Agricultural Policy, sections 1.0-11.0.

Gilliom, R.J., Alley, W.M., and Gurtz, M.E., 1995, Design of the National Water-Quality Assessment Program: Occurrence and distribution of water-quality conditions: U.S. Geological Survey Circular 1112, $33 \mathrm{p}$.

Hayes, T.B., and others, 2002, Hermaphroditic demasculinized frogs after exposure to the herbicide atrazine at low ecologically relevant doses: Proceedings of the National Academy of Sciences of the United States, accessed on December 6, 2002, at URL http://www.pnas.org/cgi/doi/10.1073/ pnas.082121499

Helsel, D.R., and Cohn, T.A., 1988, Estimation of descriptive statistics for multiply censored water quality data: Water Resources Research, v. 24, p. 1997-2004.

Helsel, D.R., and Hirsch, R.M., 1992, Statistical methods in water resources: Amsterdam, Elsevier Science Publishers B.V., Studies in Environmental Science, v. 49, 522 p.

International Joint Commission United States and Canada, 1978, Great Lakes Water Quality Agreement of 1978, as amended by Protocol signed November 18, 1987, Annex I, Specific objectives: International Joint Commission United States and Canada, accessed on August 5, 2003 at URL http://www.ijc.org/agree/quality.html\#ann1

Kalkhoff, S.J., Kolpin, D.W., Thurman, E.M., Ferrer, I., and Barcelo, D., 1998, Degradation of chloroacetanilide herbicides - the prevalence of sulfonic and oxanilic acid metabolites in Iowa groundwaters and surface waters: Environmental Science \& Technology, v. 32, no. 11, p. 1738-1740.
Kalkhoff, S.J., Lee, K.E., Porter, S.D., Terrio, P.J., and Thurman, E.M., 2003, Herbicides and herbicide degradation products in upper Midwest agricultural streams during August base-flow conditions: Journal of Environmental Quality, v. 32, p. 1025-1035.

Larson, S.J, Gilliom, R.J, and Capel, P.D., 1999, Pesticides in streams of the United States, initial results from the National Water-Quality Assessment Program: U.S. Geological Survey Water-Resources Investigations Report 98-4222, 92 p.

Leahy, P.P., Rosenshein, J.S., and Knopman, D.S., 1990, Implementation plan for the National Water-Quality Assessment Program: U.S. Geological Survey Open-File Report 90-174, $10 \mathrm{p}$.

Lee, E.A., Kish, J.L., Zimmerman, L.R., and Thurman, E.M., 2001, Methods of analysis by the U.S. Geological Survey Organic Geochemistry Research Group-Update and additions to the determination of chloroacetanilide herbicide degradation compounds in water using high-performance liquid chromatography/mass spectrometry: U.S. Geological Survey Open-File Report 01-10, 17 p.

Lindsey, B.D., Breen, K.J., Bilger, M.D., Brightbill, R.A., 1998, Water quality in the Lower Susquehanna River Basin, Pennsylvania and Maryland, 1992-95: U.S. Geological Survey Circular 1168, 38 p.

Martin, J.D., Gilliom, R.J., and Schertz, T.J., 1999, Summary and evaluation of pesticides in field blanks collected for the National Water-Quality Assessment Program, 1992-95: U.S. Geological Survey Open-File Report 98-412, 102 p.

Martin, J.D., 2002, Variability of pesticide detections and concentrations in field replicate water samples collected for the National Water-Quality assessment Program, 1992-1997: U.S. Geological Survey Water-Resources Investigations Report 01-4178, 84 p.

Meister Publishing Company, 2000, Farm chemicals handbook 2000: Willoughby, Ohio, Meister Publishing Company, v. 86 , p. A1 to F24.

Mueller, D.K., Martin, J.D., and Lopes, T.J., 1997, Qualitycontrol design for surface-water sampling in the National Water-Quality Assessment Program: U.S. Geological Survey Open-File Report 97-223, 17 p.

Oblinger Childress, C.J., Foreman, W.T., Connor, B.F., and Maloney, T.J., 1999, New reporting procedures based on long-term method detection levels and some considerations for interpretations of water-quality data provided by the U.S. Geological Survey National Water Quality Laboratory: U.S. Geological Survey Open-File Report 99-193, 19 p.

Phillips, P.J., Wall, G.R., Thurman, E.M., Eckhardt, D.A., and Vanhoesen, J., 1999, Metolachlor and its metabolites, in tile drain and stream runoff in the Canajoharies Creek watershed: Environmental Science and Technology, v. 33, no. 20, p. 3531-3537.

Reiser, R.G., and O'Brien, A.K., 1999, Pesticides in streams in New Jersey and Long Island, New York, and relation to land use: U.S. Geological Survey Water-Resources Investigations Report 98-4261, 12 p. 
Sandstrom, M.W., 1995, Filtration of water-sediment samples for determination of organic compounds: U.S. Geological Survey Water-Resources Investigations Report 95-4105, $13 \mathrm{p}$.

Shelton, L.R., 1994, Field guide for collecting and processing stream-water samples for the National Water-Quality Assessment Program: U.S. Geological Survey Open-File Report 94-455, $42 \mathrm{p}$.

Thelin, G.P., and Gianessi, L.P., 2000, Method for estimating pesticide use for county areas of the conterminous United States: U.S. Geological Survey Open-File Report 00-250, $62 \mathrm{p}$.

U.S. Environmental Protection Agency, (undated), Cyanazine pesticide voluntarily canceled and uses phased out: Office of Pesticide Programs, International Pesticide Notice, accessed November 2, 2001 at URL http://www.epa.gov/oppfead1/ 17b/cyanazin.htm

U.S. Environmental Protection Agency, 2003a, Acetochlor: Office of Pesticide Programs, accessed on September 25, 2003, at URL http://www.epa.gov/oppefed1/aceto/index.htm

U.S. Environmental Protection Agency, 2003b, Carbaryl interim reregistration eligibility decision facts, accessed on September 25, 2003, at URL http://www.epa.gov/oppsrrd1/ REDs/factsheets/carbaryl_factsheet.pdf

U.S. Environmental Protection Agency, 2003c, Integrated Risk Information System (IRIS) database: U.S. Environmental Protection Agency, Office of Research and Development, National Center for Environmental Assessment, accessed on August 7, 2003, at URL http://www.epa.gov/iris

U.S. Environmental Protection Agency, 2002a, Overview of atrazine risk assessment, accessed September 25, 2003, at URL http://www.epa.gov/oppsrrd1/reregistration/atrazine/ srrd_overview_may02.pdf

U.S. Environmental Protection Agency, 2002b, 2002 Edition of the Drinking Water Standards and Health Advisories: U.S. Environmental Protection Agency, Office of Water, EPA822-R-02-038, Summer 2002, accessed January 16, 2003, at URLs http://www.epa.gov/ost/drinking/standards/ and http://www.epa.gov/waterscience/drinking/standards/ dwstandards.pdf
U.S. Environmental Protection Agency, 2001, Diazinon revised risk assessment and agreement with registrants, accessed on September 25, 2003, at URL http://www.epa.gov/oppsrrd1/ op/diazinon/agreement.pdf

U.S. Environmental Protection Agency, 2000, Chlorpyrifos revised risk assessment and risk mitigation measures: http:// www.epa.gov/pesticides/op/chlorpyrifos/consumerqs.htm (accessed on September 25, 2003).

U.S. Environmental Protection Agency, 1998, Reregistration eligibility decision facts, alachlor: EPA-738-F-98-018, accessed September 25, 2003, at URL http://www.epa.gov/ oppsrrd1/REDs/factsheets/0063fact.pdf

U.S. Environmental Protection Agency, 1997, Reregistration eligibility decision facts, pendimethalin: EPA-738-F-97-007, 9 p., accessed on September 25, 2003, at URL http:// www.epa.gov/oppsrrd1/REDs/factsheets/0187fact.pdf

U.S. Environmental Protection Agency, 1996, Reregistration eligibility decision facts, trifluralin: EPA-738-F-95-007, accessed on September 25, 2003, at URL http:// www.epa.gov/oppsrrd1/REDs/factsheets/0179fact.pdf

U.S. Environmental Protection Agency, 1995, Reregistration eligibility decision facts, metolachlor: EPA-738-F-95-007, accessed on September 25, 2003, at URL http:// www.epa.gov/oppsrrd1/REDs/factsheets/0001fact.pdf

U.S. Environmental Protection Agency, 1994, Reregistration eligibility decision facts, tebuthiuron: EPA-738-F-94-006, accessed on September 25, 2003, at URL http:// www.epa.gov/oppsrrd1/REDs/factsheets/0054fact.pdf

Wall, G.R., Riva-Murray, K., and Phillips, P.J., 1998, Water quality in the Hudson River Basin, New York and adjacent states, 1992-95: U.S. Geological Survey Circular 1165, 32 p.

Zaugg, S.D., Sandstrom, M.W., Smith, S.G., and Fehlberg, K.M., 1995, Methods of analysis by the U.S. Geological Survey National Water Quality Laboratory-determination of pesticides in water by $\mathrm{C}-18$ solid-phase extraction and capillary-column gas chromatography/mass spectrometry with selected-ion monitoring: U.S. Geological Survey Open-File Report 95-181, 49 p. 
For additional information write to:

District Chief

U.S. Geological Survey

New Jersey District

Mountain View Office Park

810 Bear Tavern Road

West Trenton, NJ 08628

or access the New Jersey District web site at: http://nj.usgs.gov 